\title{
6000 years of environmental changes recorded in Blue Lake, South Australia, based on ostracod ecology and valve chemistry
}

\author{
Chris Gouramanis *, Daniel Wilkins ${ }^{1}$, Patrick De Deckker \\ Research School of Earth Sciences, The Australian National University, Canberra ACT, 0200, Australia
}

\section{A R T I C L E I N F O}

\section{Article history:}

Received 24 December 2009

Received in revised form 11 August 2010

Accepted 12 August 2010

Available online 19 August 2010

\section{Keywords:}

Aquifers

AMS ${ }^{14} \mathrm{C}$ dating

Reservoir effect

Stable isotopes of biogenic carbonate

Trace elements

$\mathrm{Mg} / \mathrm{Ca}$

$\mathrm{Sr} / \mathrm{Ca}$

$\mathrm{Na} / \mathrm{Ca}$

Holocene

\begin{abstract}
A B S T R A C T
A $4 \mathrm{~m}$ long core taken from the freshwater Blue Lake crater near the township of Mount Gambier in southeastern South Australia provided a high-resolution palaeoclimatic record for the last six millennia. Accelerator Mass Spectrometry (AMS) radiocarbon $\left({ }^{14} \mathrm{C}\right.$ ) dates were obtained from organic plant fibres and biogenic carbonates from the laminated sequence of the core and from a modern water sample. Large discrepancies between the radiocarbon ages determined from plant fibres and biogenic carbonates indicate the presence of a time-variable lacustrine reservoir, which is consistent with what is known of the lake's hydrology.

Ostracod assemblages, associated with stable isotope $\left(\delta^{13} \mathrm{C}, \delta^{18} \mathrm{O}\right)$ analyses and, in combination with $\mathrm{Mg} / \mathrm{Ca}, \mathrm{Sr} / \mathrm{Ca}$ and $\mathrm{Na} / \mathrm{Ca}$ analyses done on ostracod valves, infer salinity, temperature and water level changes in Blue Lake over the last 6 millenia. The influence of local aquifers through time has also been determined from the $\mathrm{Na} / \mathrm{Ca}$ of ostracod valves. Approximately 900 year cycles are evident in the $\delta^{13} \mathrm{C}$ record from $5.4 \mathrm{ka}$ to $1.8 \mathrm{ka}$.

The history of Blue Lake records an initial period of high hydrological variability around $6 \mathrm{ka}$, becoming increasingly deeper as groundwater flowed into the basin. By 4 ka, the lake had reached steady state with the lake level fluctuating by as much as $9 \mathrm{~m}$, although significant geochemical variations represent temperature fluctuations until European settlement near the lake in 1839.
\end{abstract}

(c) 2010 Elsevier B.V. All rights reserved.

\section{Introduction}

Hydrologically closed volcanic crater lakes from southeastern Australia act as giant rain gauges with lake levels responding to variations in the regional climate (Currey, 1970; Bowler, 1981; De Deckker, 1982a; Jones et al., 1998; 2001). Changes in climate affect crater-lake water levels through variations of $\mathrm{E} / \mathrm{P}$ (evaporation/precipitation). Increasing (decreasing) $\mathrm{E} / \mathrm{P}$ results in shallowing (deepening) of the lakes' water level (Bowler, 1981; Jones et al., 1998, 2001). The absence of river inflow or outflow, a well defined rim and the steep-sided nature of these craters mean the nonwater surface area of the catchment is relatively small compared to the water surface area (De Deckker, 1982a; Jones et al., 1998, 2001). As such, surface flow into these lakes is negligible and the predominant water source is from precipitation. When water levels are below the crater rim, water loss is mostly through evaporation. Some leakage may also occur through the porous lithologies (e.g. scoria) of the craters. Thus, variation in lake level also engenders either concentration or dilution of dissolved ions in the water and, thus, changes salinity (Currey, 1970; De Deckker and Forester, 1988).

\footnotetext{
* Corresponding author.

E-mail addresses: christos@ems.anu.edu.au (C. Gouramanis), Daniel.Wilkins@aad.gov.au (D. Wilkins), Patrick.dedeckker@anu.edu.au (P. De Deckker).

${ }^{1}$ Present address: Australian Antarctic Division, Department of the Environment, Water, Heritage and the Arts, Kingston, Tasmania 7050, Australia.
}

Unlike many of the volcanic crater lakes in southeastern Australia, Blue Lake intersects the regional groundwater table and, at present, the lake level is predominantly controlled by groundwater flow, E/P and pumping for human consumption (Holmes and Waterhouse, 1983; Ramamurthy et al., 1985; B.L.M.C., 2001). Groundwater inflowing into Blue Lake is chemically distinct from rainwater having chemically reacted with the surrounding basalt and limestone (Blackburn and McLeod, 1983; Love et al., 1993, 1994). The significant groundwater influence in Blue Lake complicates interpretations of lake level variation through E/P variations, and to solve this effect, evidence is examined from several proxy records preserved in the lake's sediment.

This paper describes the high-resolution palaeoenvironmental and palaeoclimatic changes recorded in the Holocene sediments and associated fossil microbiota and hydrochemistry of Blue Lake. In conjunction with a companion paper focussing on the crater Lakes Keilambete and Gnotuk located in western Victoria, some $200 \mathrm{~km}$ east of Blue Lake (Wilkins et al., in preparation), this paper seeks to provide geochronologically-constrained, high-resolution lacustrine Holocene paleoenvironmental and paleoclimatic histories from southeastern Australia.

\section{Regional setting}

\subsection{Site description}

Blue Lake ( $37^{\circ} 50.713^{\prime} \mathrm{S}, 140^{\circ} 46.486^{\prime} \mathrm{E}$ ) is the largest and deepest of four lakes (Valley, Leg of Mutton and Brownes Lakes) in the maar 
complex near the township of Mount Gambier in South Australia (Fig. 1). The water from Blue Lake has been used as Mount Gambier's water supply since 1883 and is pumped from the northern crater rim just below the water's edge.

Tamuly (1970) described Blue Lake's surface area, volume and mean and maximum depths as $0.6 \mathrm{~km}^{2}, 36.8$ million $\mathrm{m}^{3}, 61 \mathrm{~m}$ and $77 \mathrm{~m}$, respectively. The catchment area of Blue Lake is a mere $10 \%$ greater than the lake's surface area. The very steep crater walls and small surface area to volume ratio of the lake indicate that the primary mechanisms for water to enter the lake system are via precipitation and groundwater flow (Fig. 1) (see Herczeg et al., 2003).

Tamuly (1970) showed that Blue Lake is oligotrophic and monomictic, becoming thermally stratified in October (austral spring). Peak stratification occurs in January to February (summer) with surface waters recording temperatures greater than $22^{\circ} \mathrm{C}$, while bottom waters remain relatively constant at about $13^{\circ} \mathrm{C}$ all year round (Tamuly, 1970; Vanderzalm et al., 2009). Complete thermal mixing occurs during the winter months from June to September (Telfer, 2000; Vanderzalm et al., 2009). This time coincides with the colour change from grey to blue by the precipitation of tiny calcite crystals in the water column and concentrating humic substances during the degassing of $\mathrm{CO}_{2}$ during stratification (Telfer, 2000). Turner et al. (1984) found that Blue Lake is always supersaturated with respect to calcium carbonate.

\subsection{Modern climatology}

The local climate is characterised by cool, wet winters and hot, dry summers. The lowest mean minimum/maximum temperatures at Mount Gambier occur in July $\left(5.3{ }^{\circ} \mathrm{C} / 13.8^{\circ} \mathrm{C}\right)$ and the highest in
February $\left(11.9^{\circ} \mathrm{C} / 24.8^{\circ} \mathrm{C}\right)$. Regional precipitation decreases northeast of the southern coast (Blackburn and McLeod, 1983); however, Blue Lake is within $25 \mathrm{~km}$ of the coast. Mean minimum precipitation $(29 \mathrm{~mm})$ occurs in February, and mean maximum precipitation (107.1 mm) occurs in July (Fig. 2) (Data courtesy of the Bureau of Meteorology, http://www.bom.gov.au/climate/averages/tables, 2008).

\subsection{Regional geology}

Blue Lake occurs in a complex maar crater located in the basaltic and tuffaceous Newer Volcanics in southeastern South Australia that forms part of the western portion of the Otway Basin. The Blue Lake volcanic structure intersects the upper part of the Late Palaeocene to Middle Eocene Dilwyn Formation and the conformably overlying Middle to Late Miocene Gambier Limestone (Fig. 1). The Dilwyn Formation represents a transition from a sandy fluvial environment to a deltaic/interdistributary bay environment, opening to the fossiliferous carbonate open-marine shelf Gambier Limestone (Waterhouse, 1977; Love et al., 1993). Li et al. (2000) identified seven diachronous members of the Gambier Limestone including the fractured dolomitic Camelback Member.

\subsection{Geochronology}

Numerous studies have been conducted to determine the age of the volcanism of the Blue Lake complex (Gill, 1955; Blackburn, 1966; Kigoshi and Kobayashi, 1966; Blackburn et al., 1982) and the lacustrine sediments within the Blue Lake catchment (Ayliffe, 1983; Leaney et al., 1995). Ages for volcanism in the Blue Lake complex have ranged from 38
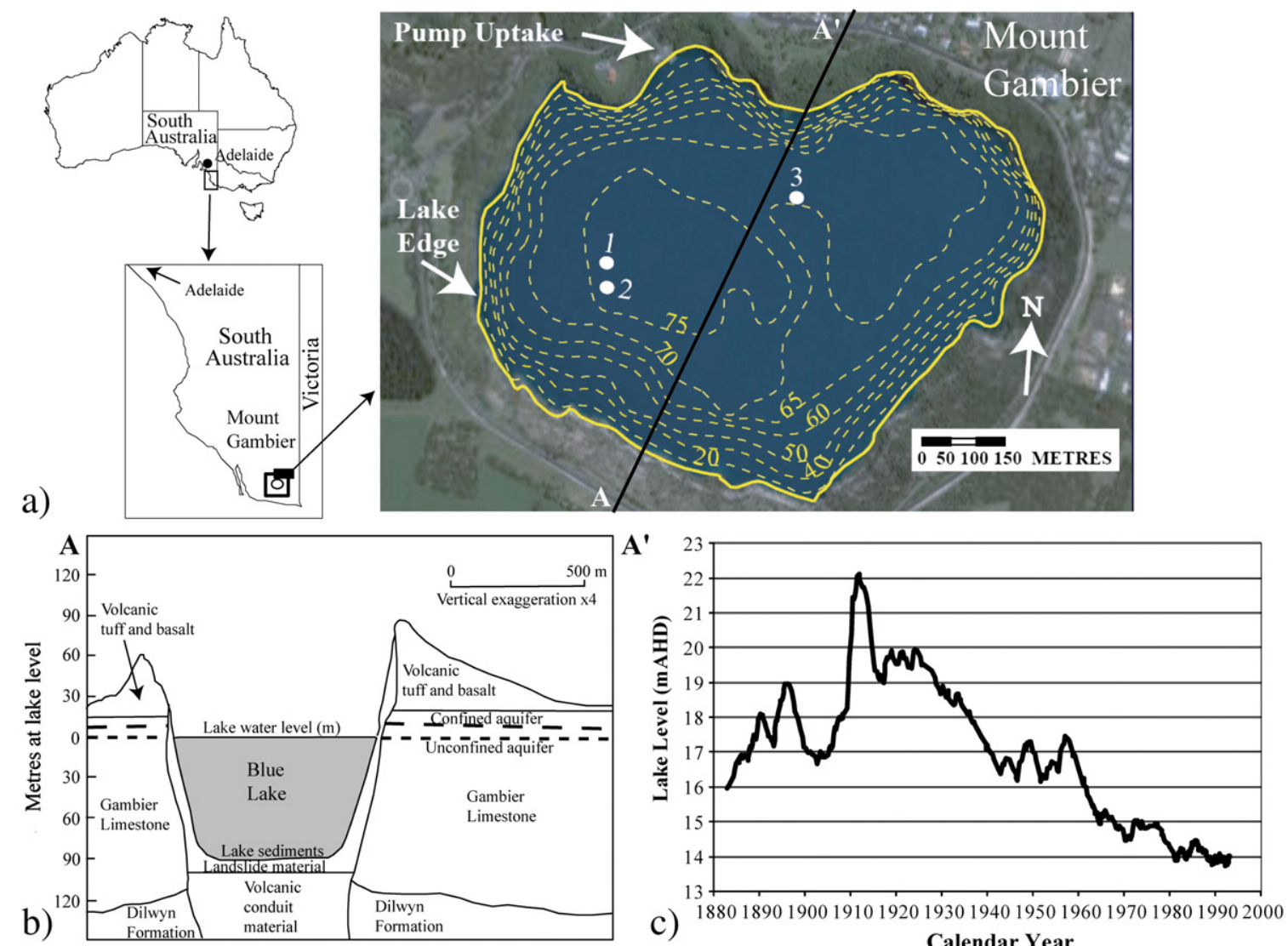

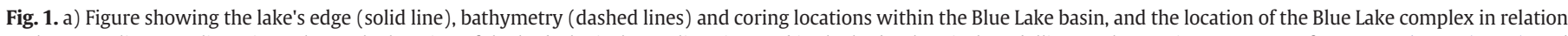

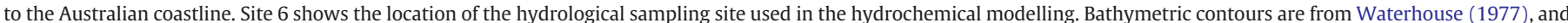

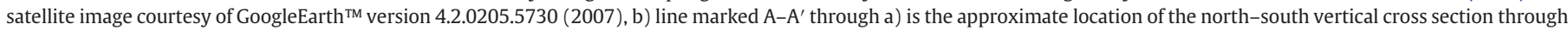

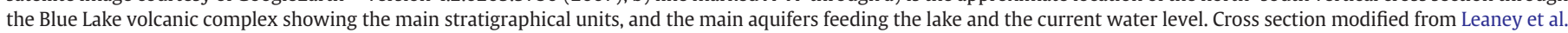
(1995) and Sheard (1978), and c) is the historical (1882 to 1993) lake level curve for Blue Lake (from D.W.L.B.C., 2010). 


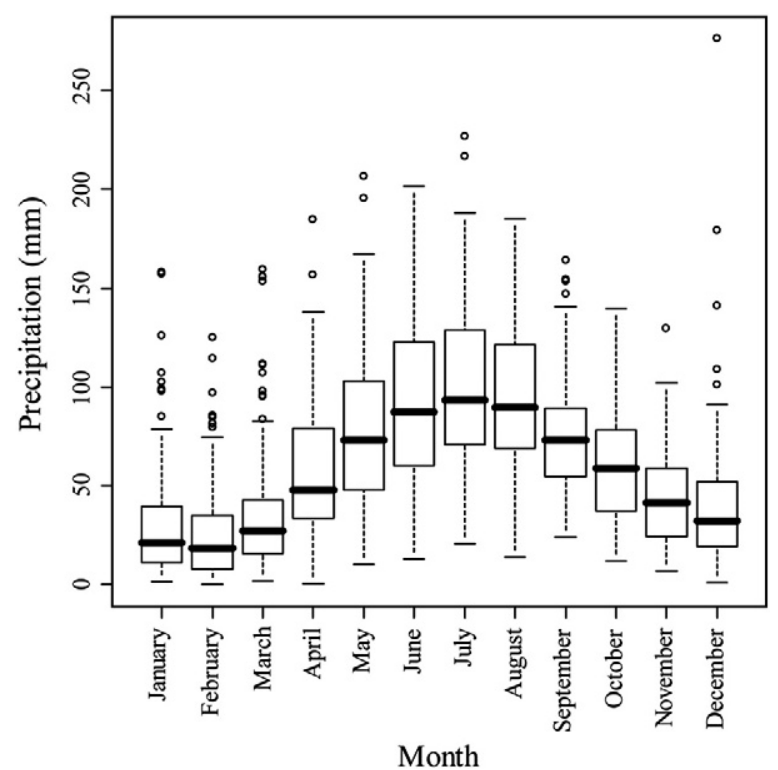

Fig. 2. Boxplots of the monthly precipitation at Mount Gambier from 1861 to 2004 (http://www.bom.gov.au/climate/averages/tables, 2008). The thin outlined boxes show the span between 25 and 75 percentiles, the thick solid lines show the median value, lines extending from the boxes show the minimum and maximum values and outliers are represented as open circles.

$400 \mathrm{yr}$ BP (Barton and McElhinny, 1980) to $1410 \mathrm{yr}$ BP (Blackburn, 1966; Kigoshi and Kobayashi, 1966). Leaney et al. (1995) calculated a maximum age of $28000 \mathrm{yr}$ BP from basal bulk sediment samples.

\subsection{Water chemistry and regional hydrology}

The Blue Lake crater intersects two aquifers, the unconfined Gambier aquifer in the Gambier Limestone and the confined Dilwyn aquifer in the Dilwyn Formation (Fig. 1). Holmes and Waterhouse (1983) produced potentiometric maps that describe a high gradient of groundwater flow from $5 \mathrm{~km}$ northeast of Mount Gambier, which decreases to almost a horizontal flow into the Blue Lake area through the Gambier Limestone. The groundwater flow through the Dilwyn Formation is almost horizontal and also from the northeast.

The Camelback Member of the Gambier Limestone is approximately $50 \mathrm{~m}$ below the current lake level on the northern face of the lake (B.L.M.C., 2006; Vanderzalm et al., 2009; Lawson pers. comm.) and contributes $85 \%$ of the groundwater inflow to the lake from the Gambier aquifer (Ramamurthy et al., 1985). The Dilwyn aquifer contributes the remaining 15\% (Ramamurthy et al., 1985). The drop in Blue Lake water level from 22 m to 13 m above AHD (Australian Height Datum) from 1911 to 1993 (Fig. 1) is strongly correlated with the decline in regional precipitation variation in the Mount Gambier area during this period (B.L.M.C., 2006). However, pumping of Blue Lake for Mount Gambier's water supply has steadily increased between 1960 and $2001\left(4 \times 10^{6} \mathrm{~m}^{3} / \mathrm{yr}\right.$ determined by Turner et al. (1984)) but has not caused variation in the lake level (B.L.M.C., 2006). This increased pumping has resulted in greater inflow rates of the groundwater to between $5 \times 10^{6}$ and $6.5 \times 10^{6} \mathrm{~m}^{3} / \mathrm{yr}$ (Turner et al., 1984). The water residence time has also been calculated to be 6 to 10 years (Turner et al., 1984; Herczeg et al., 2003). It is currently unknown how much groundwater flows from Blue Lake.

In two extensive studies of the regional hydrology, Love et al. (1993, 1994) showed that recharge of the Gambier aquifer was via downward percolation of local precipitation. The predominant region of recharge for the Dilwyn aquifer, on the other hand, outcrops in a small zone near Nangwarry, some $30 \mathrm{~km}$ north of Mount Gambier. The Gambier and Dilwyn aquifers' dominant flow is southward, towards the coast in the Mount Gambier region and, just north of Mount Gambier, the hydraulic potential shifts from downward leakage from the Gambier aquifer to significant upward leakage from the Dilwyn aquifer (Love et al., 1993).

The groundwater that reaches Blue Lake is predominantly from horizontal transmission from recharge areas north of the Blue Lake volcanic crater (Waterhouse, 1977; Love et al., 1993, 1994). North of Blue Lake, the flow rates of both aquifers is slow (Waterhouse, 1977) and the top of the water table resides well below the basaltic scoria (Fig. 1). This means that chemically altered precipitation that has percolated through the basaltic scoria contributes negligible volumes to the overall hydrologic budget of the aquifers or Blue Lake. There is also no direct spring seepage from the scoria cone into the lake.

Love et al. (1994) measured low radiocarbon concentrations in confined and unconfined aquifers from a transect passing close to Mt Gambier. Modeled groundwater ages from the confined aquifers were between 2500 and 35000 years (61.2 and 1.3 percent modern carbon $(\mathrm{pmc})$ ), whereas the unconfined aquifers contained between 62.5 and 78.2 pmc (equating to modeled groundwater ages of between 950 and 2500 years) (Love et al., 1994). In the unconfined aquifers, the ages are consistent with mixing of older water with modern and younger soil radiocarbon. The radiocarbon ages from the Gambier wells tended to be younger, but were still in the order of 2000 to 3000 years (Love et al., 1994). We note, however, that the water percolating through a limestone terrain would provide "old" bicarbonate to the groundwater.

Love et al. $(1993,1994)$ also provided some water chemistry data for two Dilwyn aquifer and the unconfined Gambier aquifer that are relevant to our study, and these are presented in Table 1. Modern and modelled hydrological data for Blue Lake is presented in the Supplementary information.

\section{Ostracods}

Ostracods are microcrustaceans found in most Australian inland waters from freshwater to salinities close to $200 \mathrm{~g} / \mathrm{L}$ (De Deckker, 1981, 1983). Ostracods secrete low-Mg calcite valves, which they moult up to nine times before reaching adulthood. Following the moulting of the valves as the ostracod grows, the chemical elements of the ostracod valves come directly from the ambient water (Turpen and Angell, 1971), and, as such, can be used as hydrochemical indicators. Chivas et al. (1983, 1985, 1986) and De Deckker et al. (1999) determined the geochemical relationships between the uptake of trace metal $(\mathrm{Mg}, \mathrm{Sr})$ substitution of $\mathrm{Ca}$ in the $\mathrm{CaCO}_{3}$ by ostracods and the ambient water.

Chivas et al. $(1983,1985,1986)$ were the first to show that for $\mathrm{Mg}$ there is a strong temperature effect on $\mathrm{Mg}$ incorporation in the ostracod calcite, but that this relationship also depended on the $\mathrm{Mg} / \mathrm{Ca}$ of the host water. Chivas et al. $(1983,1985,1986)$ also showed that Sr uptake is controlled by the $\mathrm{Sr} / \mathrm{Ca}$ of the host water. Nevertheless, De Deckker et al. (1999) suggested that there may be a weak temperature influence on $\mathrm{Sr} / \mathrm{Ca}_{\mathrm{valve}}$ in the euryhaline Cyprideis australiensis, and Gouramanis and De Deckker (2010) have recently argued, using Australian examples, that the $\mathrm{Sr} / \mathrm{Ca}$ in ostracod valves is affected by the $\alpha \mathrm{HCO}_{3}^{-}$with a decrease in the $\mathrm{Sr} / \mathrm{Ca}$ that is correlated with alkalinity increase. However, Ito and Forester (2009) suggested that utilising ostracod valve chemistry as proxies for environmental parameters may oversimplify the true nature and causes of variation in any lake.

Table 1

Water samples collected and analysed by Love et al. $(1993,1994)$ from the Dilwyn (DIL) and Gambier (GAM) aquifers in the Blue Lake region.

\begin{tabular}{lllllll}
\hline Sites & $\begin{array}{l}\text { Distance from } \\
\text { South Coast } \\
(\mathrm{km})\end{array}$ & $\begin{array}{l}\mathrm{TDS} \\
\mathrm{g} / \mathrm{L})\end{array}$ & $\mathrm{Mg} / \mathrm{Ca}$ & $\mathrm{Na} / \mathrm{Ca}$ & $\delta{ }^{18} \mathrm{O}$ & $\delta^{13} \mathrm{C}$ \\
\hline DIL052 & 24 & 0.816 & 0.43 & 2.26 & -3.5 & -10.6 \\
DIL016 & 20 & 0.795 & 0.6 & 2.55 & -4.4 & -11.9 \\
GAM011 & 22 & 0.575 & 0.42 & 1.42 & -4.9 & \\
GAM014 & 36 & & & & & -9.3 \\
\hline
\end{tabular}


The incorporation of the stable isotopes $\left(\delta^{18} \mathrm{O}\right.$ and $\left.\delta^{13} \mathrm{C}\right)$ into ostracod valves is due in part to the isotopic signature of the host waters, and temperature for $\delta^{18} \mathrm{O}$, and the isotopic composition of dissolved inorganic carbon for $\delta^{13} \mathrm{C}$ (von Grafenstein et al., 1999b; Holmes and Chivas, 2002; Ito et al., 2003).

The oxygen isotopic signature of the host water is derived from a complex interplay between ambient air temperature and evaporation, water temperature, groundwater inflow and outflow, precipitation and precipitation sources, and water depth (von Grafenstein et al., 1999b). The carbon isotopic signature is also a complex interaction between atmospheric $\mathrm{CO}_{2}$ and dissolved $\mathrm{CO}_{2}$, plant and algal photosynthesis, oxidation and reduction reactions in the sediments within and surrounding the lake, overland water flow, groundwater inflow and outflow and methanogenesis (Curry et al., 1997), as well as possible sulphate reduction (Ito and Forester, 2009).

Both trace metal and stable isotope analysis of ostracod valves have been utilised as excellent proxies for hydrochemical conditions at the time of ostracod valve calcification, and, as such, have been used for lacustrine palaeoenvironmental and palaeoclimatic reconstructions (Chivas et al., 1985; Engstrom and Nelson, 1991; Chivas et al., 1993; Holmes, 1996; Holmes et al., 1997; De Deckker et al., 1999; von Grafenstein et al., 1999a; Ricketts et al., 2001; Ito, 2002; Schwalb, 2003; Anadon et al., 2006; Mischke and Wunnemann, 2006).

\section{Methods}

Three, approximately $4 \mathrm{~m}$ long, Mackereth cores were obtained from Blue Lake (Fig. 1) in November 2002. The three cores were cut into $1 \mathrm{~m}$ lengths, opened and photographed using a Nikon D70 digital camera with a Nikon 18-70 mm f/3.5-4.5 DX lens. Comparison of the three cores (not shown) resulted in core BL01 being used for geochronology, faunal and geochemical as well as sedimentological analysis as it was the longest. Photographs of the core and sedimentological interpretations are available as Supplementary Fig. S2 and Table S1 (see Palaeogeography, Palaeoclimatology, Palaeoecology website).

Sediment and faunal samples of the upper laminated part of the core (above $239.6 \mathrm{~cm}$ ) were taken of individual laminae or groups of very thin laminae and ranged in thickness from 4 to $15 \mathrm{~mm}$. In the unlaminated part of the core (below $239.6 \mathrm{~cm}$ ), a sample of one centimetre thickness was taken every $4 \mathrm{~cm}$. In all, 200 horizons were sampled from core BL01. These samples had the outer few millimetres cut away to remove potential contamination during the coring procedure.

The sediment samples were weighed, oven dried at $50{ }^{\circ} \mathrm{C}$ and reweighed to obtain the normalised water loss. A $3 \% \mathrm{H}_{2} \mathrm{O}_{2}$ solution was added to the dry sample placed in clean $125 \mathrm{~mL}$ jars to disaggregate clays and clean the carbonate fraction. The samples were filtered through $120 \mu \mathrm{m}$ aluminium sieves using tap water, oven dried at $50^{\circ} \mathrm{C}$, and visually checked to ensure the ostracod valves were clean. Where ostracod valves were unclean, the process was repeated.

Where present, ostracods were identified to species level, picked and counted for standardised quantitative faunal variation, and trace metal and stable isotope analysis of selected valves could be undertaken.

Eight carbonate and one charcoal sample for radiocarbon analysis (prefixed by ANUA) were hand-picked from the sediment samples, purified and graphitised at the Department of Nuclear Physics, Research School of Physical Sciences and Engineering (RSPhysSE) at the Australian National University (ANU) (Wilkins, 2009). The graphite targets were measured on the 14UV tandem accelerator (Fifield et al., 1994). Six additional fibrous samples of terrestrial origin (prefixed by OZJ) were processed and measured at the Australian Nuclear Science and Technology Organisation (ANSTO) (Fink et al., 2004). Carbonate was precipitated from a modern water sample (prefixed by ANUSSA) and analysed with the Single Stage AMS (SSAMS) facility at the ANU (Fallon, pers. comm.). These ages are presented in Table 2.
Raw radiocarbon ages were corrected for $\delta^{13} \mathrm{C}$ fractionation using values measured from the graphite target (in the case of the OZJ and ANUSSA samples) or from coeval samples (in the case of the ANUA carbonate samples). For samples where $\delta^{13} \mathrm{C}$ was not measured (the ANUA charcoal sample), a generic value was substituted from the table of Stuiver and Polach (1977) as standard practice. All of the organic radiocarbon ages were calibrated using Calib 5.0.1 (Stuiver and Reimer, 1993) with the southern hemisphere dataset of McCormac et al. (2004). These samples have been calibrated assuming a sedimentary age span calculated from first-order accumulation rates (10 to 40 years) rather than an instantaneous age. The carbonate ages have not been calibrated, due to the presence of variable reservoir ages and the complexity of the groundwater hydrology.

\subsection{Ostracod transfer function}

The salinity $\left(\log _{10}\right.$ (TDS)) of Blue Lake is reconstructed from the fossil ostracod fauna preserved in core BL01 using the C2 program (Juggins, 2003). The transfer function employed utilised the weighted average of 10 modern analogues technique (WMAT) using the BrayCurtis percent dissimilarity coefficient and Bootstrapping crossvalidation with 4999 iterations (Gouramanis, 2009).

The modern analogue data include 496 samples from southeastern Australia, 30 from southwestern Western Australia, 10 samples from northwestern Western Australia and one sample from central Australia. The Western Australian and central Australian data are included since these sites include hydrochemical data for sites containing Candonopsis tenuis. This species is found in southeastern Australia, but no hydrochemical data is reported. Thus, it is assumed that the salinity tolerance of this species is the same across the continent (Gouramanis, 2009). There is no ecological data available for Ilyodromus smaragdinus, and this species was not included in the modelling of $\log _{10}$ (TDS). All other species have been included. Further details regarding the ostracod salinity transfer function are available in Gouramanis (2009).

Table 2

Geochronology of samples from Blue Lake Core BL01.

\begin{tabular}{|c|c|c|c|c|c|}
\hline Sample Code & $\begin{array}{l}\text { Depth } \\
(\mathrm{cm})\end{array}$ & Material & $\delta^{13} \mathrm{C}$ & $\begin{array}{l}{ }^{14} \mathrm{C} \text { age }^{\mathrm{b}} \\
\left({ }^{14} \mathrm{C} \text { yr BP } \pm 1 \sigma\right)\end{array}$ & $\begin{array}{l}\text { Calibrated age } \\
(\text { cal.yr } \mathrm{BP} \pm 1 \sigma)\end{array}$ \\
\hline ANUSSA2309 & 0 & Water & -11 & $2395 \pm 30$ & \\
\hline ANUA36707 & 13 & $\begin{array}{l}\text { Mixed } \\
\text { carbonate }^{a}\end{array}$ & -7 & $3070 \pm 180$ & \\
\hline OZJ950 & 16 & Plant fibres & -24 & $800 \pm 60$ & $700 \pm 35$ \\
\hline ANUA36714 & 25 & Charcoal & -24 & $1230 \pm 200$ & $1100 \pm 185$ \\
\hline ANUA36708 & 25 & Ostracod calcite & -7 & $2070 \pm 180$ & \\
\hline ANUA36028 & 53 & $\begin{array}{l}\text { Mixed } \\
\text { carbonate }^{a}\end{array}$ & -7 & $4260 \pm 180$ & \\
\hline ANUA36709 & 66 & $\begin{array}{l}\text { Mixed } \\
\text { carbonate }^{\mathrm{a}}\end{array}$ & -7 & $5350 \pm 170$ & \\
\hline ANUA36029 & 69 & Ostracod calcite & -7 & $4780 \pm 185$ & \\
\hline OZJ951 & 81 & Plant fibres & -25 & $3010 \pm 60$ & $3120 \pm 105$ \\
\hline OZJ952 & 102 & Plant fibres & -25 & $3390 \pm 60$ & $3560 \pm 80$ \\
\hline ANUA36710 & 130 & $\begin{array}{l}\text { Charophyte } \\
\text { oogonia }\end{array}$ & -7 & $6390 \pm 185$ & \\
\hline OZJ953 & 141 & Plant fibres & -20 & $4360 \pm 70$ & $4900 \pm 80$ \\
\hline ANUA36711 & 147 & $\begin{array}{l}\text { Mixed } \\
\text { carbonate }^{a}\end{array}$ & -7 & $7170 \pm 210$ & \\
\hline OZJ954 & 185 & Plant fibres & -27 & $4650 \pm 50$ & $5260 \pm 185$ \\
\hline OZJ955 & 203 & Plant fibres & -25 & $4770 \pm 70$ & $5450 \pm 130$ \\
\hline ANUA36030 & 208 & Ostracod calcite & -1 & $6890 \pm 190$ & \\
\hline
\end{tabular}

a Mixed carbonate samples consisting of ostracods, juvenile lacustrine gastropods and or lacustrine bivalves. Inorganic carbonate and foraminifera were avoided (as numerous reworked marine foraminifera of Tertiary age were identified in the samples).

b Radiocarbon ages are presented at $1 \sigma$, ANUA ages incorporate a further $2 \%$ error added in quadrature with the statistical error to incorporate accelerator system reproducibility.

c Only organic ages (charcoal and plant fibres) have been calibrated. Calibrated dates are reported at $1 \sigma$. 


\subsection{Trace metals and stable isotopes}

Four elements (Ca, $\mathrm{Mg}, \mathrm{Sr}$ and $\mathrm{Na}$ ) were analysed from ostracod calcitic valves on the Inductively-Coupled Plasma - Atomic Emission Spectrometer (ICP-AES) at the Department of Earth and Marine Sciences (DEMS), ANU. Approximately $30 \mu \mathrm{g}$ of clean ostracod valves from a single species were analysed using the manual feeder on the ICP-AES, and each analysis was evaluated by checking that the Relative Standard Deviation (RSD) for each element was $<5 \%$. The detection limit for the analysis of each element on the ICP-AES is 0.01 , $0.01,0.005$ and $0.1 \mathrm{mg} / \mathrm{L}$ for $\mathrm{Ca}, \mathrm{Mg}$, Sr and $\mathrm{Na}$, respectively.

Five benthic ostracod species from 148 horizons (Gomphodella australica $(\mathrm{n}=116)$, Candonocypris novaezelandiae $(\mathrm{n}=8)$, Ilyodromus smaragdinus $(\mathrm{n}=15)$, Limnocythere mowbrayensis $(\mathrm{n}=16)$ and L. dorsosicula $(\mathrm{n}=2))$ were individually analysed from core BL01 for trace metals $(\mathrm{Mg} / \mathrm{Ca}, \mathrm{Sr} / \mathrm{Ca}$ and $\mathrm{Na} / \mathrm{Ca})$. Sample sizes of $\mathrm{G}$. australica, C. novaezelandiae and I. smaragdinus ranged from one to three valves, whereas for $L$. mowbrayensis and $L$. dorsosicula, sample sizes ranged from five to 20 valves per analysis. All $\mathrm{Mg} / \mathrm{Ca}_{\text {valve }}$ were less than 0.05 suggesting that no dissolution or recalcification of the ostracod valves had occurred. All errors are less than 0.05 relative standard deviations from the mean.

Stable isotope $\left(\delta^{18} \mathrm{O}\right.$ and $\left.\delta^{13} \mathrm{C}\right)$ analyses of the calcareous valves of three ostracod species ( $G$. australica $(\mathrm{n}=93)$, C. novaezelandiae $(\mathrm{n}=8)$ and I. smaragdinus $(\mathrm{n}=14)$ ) were measured with the Finnigan MAT 251 IRMS fitted with a Kiel carbonate device at the Research School of Earth Sciences, ANU. For each analysis, three to 15 valves or fragments of valves were analysed for the species selected. The standard error for the $\delta^{18} \mathrm{O}$ and $\delta^{13} \mathrm{C}$ analyses is $\pm 0.08 \%$ and $\pm 0.05 \%$, respectively. The National Bureau of Standards calcite (NBS-19) was used as the standard for both oxygen and carbon stable isotope analysis and the offset in relation to the international Vienna Pee Dee Belemnite standard is $+1.95 \%$ ofor $\delta^{13} \mathrm{C}$ and $-2.2 \%$ ofor $\delta^{18} \mathrm{O}$ (Cali, 2000).

The stable isotope analyses of multiple ostracod species from the same horizon indicate that a constant offset occurs between the $\delta^{18} \mathrm{O}$ and $\delta^{13} \mathrm{C}$ of $\mathrm{G}$. australica and I. smaragdinus $(+0.39 \pm 0.02 \%$ and $+3.28 \pm 0.53 \%$, respectively) and between G. australica and C. novaezelandiae $(+0.76 \pm 0.27 \%$ o and $+3.48 \pm 0.45 \%$, respectively). These offsets imply that the ostracods form their valves in different habitats, knowing that some observations point to $G$. australica being interstitial compared to the other species (De Deckker, unpublished observations). However, until detailed ecological studies become available for these species, we have to rely on this assumption. Thus, G. australicanormalised $\delta^{18} \mathrm{O}$ and $\delta^{13} \mathrm{C}$ profiles $\left(\delta^{18} \mathrm{O}_{\text {norm }}\right.$ and $\left.\delta^{13} \mathrm{C}_{\text {norm }}\right)$ are defined and will be used in describing the stable isotopic trends.

Consequently, it is assumed that the single ostracod valve or multiple ostracod valves examined from a horizon represent the mean value for the trace metal and stable isotope composition at that horizon (see Holmes, 2008; Ito and Forester, 2009).

\subsection{Hydrochemical modelling}

Hydrochemical modelling of the Blue Lake waters was conducted to obtain and understanding of the within lake processes affecting carbonate precipitation. Details of the datasets used and the methodology are presented in the Supplementary information (see Palaeogeography, Palaeoclimatology, Palaeoecology website).

\section{Results}

\subsection{Geochronology}

The results of the ${ }^{14} \mathrm{C}$ dating are presented in Table 2. Fig. 3 plots the biogenic carbonate (black triangles) and the plant fibres and charcoal (black squares) AMS ${ }^{14} \mathrm{C}$ dates determined from core BL01. It is immediately apparent from the inset diagram that the biogenic carbonate ages are significantly older than the organic ages. The charcoal sample from $25 \mathrm{~cm}$ has a radiocarbon age of $1230 \pm 200{ }^{14} \mathrm{C} \mathrm{yr} \mathrm{BP}$, whereas a coeval sample of pure ostracod calcite has a radiocarbon age of $2070 \pm 180$ ${ }^{14} \mathrm{C}$ yr BP. Reservoir ages calculated from the offset between the organic and biogenic carbonate dates from the sediment core vary between 800 and 2800 years. A surface water sample from Blue Lake, collected by P. De Deckker on the 2nd September 2007, gave an age of $2395{ }^{14} \mathrm{C}$ yr BP, which is consistent with the calculated range of past lacustrine reservoirs.

Due to the uncertainties surrounding past variations in the lacustrine radiocarbon reservoir, the final age model (solid line in Fig. 3 ) includes only the calibrated ${ }^{14} \mathrm{C}$ dates from organic materials (charcoal and plant fibres), resulting in a stratigraphically consistent relationship between age and depth.

The age model also includes an assumed date from Pinus radiata pollen (an introduced species in Australia), which was found down to a depth of $10 \mathrm{~cm}$ in core BL01 (Glasgow, per. comm.). The first South Australian State Government Forest tree nursery was commissioned at the northern end of Leg of Mutton Lake in 1876 (http://www. mountgambiertourism.com.au/, 2007), thus placing the age at $10 \mathrm{~cm}$ depth at approximately 125 years before sediment collection. The error bars associated with the age model are up to \pm 230 years in the lower part of the core and as little as \pm 50 years towards the top.

As the date obtained from $207.5 \mathrm{~cm}$ was the lowest date from core BL01, the sedimentation rate between 207.5 and $203.5 \mathrm{~cm}$ has been extrapolated to the facies boundary at $242.5 \mathrm{~cm}$ depth. No ostracods are found below $222.5 \mathrm{~cm}$, and the character of the sediments changes to a homogeneous dark brown mud (Brown Clay Facies) below $242.5 \mathrm{~cm}$. Some palynological components recovered from this Brown Clay Facies are Tertiary in age (Glasgow, pers. comm.), which reflects the concentration of pollen reworked from the Tertiary limestone crater walls. No dates were obtained from the lower facies.

\subsection{Sedimentology}

Three broad sedimentological facies are identified from core BL01: a basal Brown Clay Facies from at least $393.7 \mathrm{~cm}$ depth to $239.6 \mathrm{~cm}$ depth, a Moderately Laminated Clay Facies from $239.6 \mathrm{~cm}$ depth to $12.3 \mathrm{~cm}$ depth and an upper Densely Laminated Clay Facies from $12.3 \mathrm{~cm}$ to the surface (see Supplementary information and Table S1 and Figs. S1 and S2 - see Palaeogeography, Palaeoclimatology, Palaeoecology website). Scattered throughout these upper two facies are thin $(<2 \mathrm{~cm}$ thick) turbiditic layers consisting of slumped material from the crater walls.

\subsection{Faunal associations}

Three broad ostracod faunal associations occur in core BL01; the Basal Ostracod Assemblage dominated by Limnocythere dorsosicula, Ilyodromus smaragdinus and Cypretta sp., the Intermediate Ostracod Assemblage dominated by L. mowbrayensis, Gomphodella australica, and the Upper Ostracod Assemblage dominated by L. mowbrayensis and G. maia. The three faunal associations grade into each other (Fig. 4a). Both the ostracod faunal associations and the other associated biological material (Fig. 4b) found in core BL01 are described in Table S2 (see Supplementary information).

\subsection{Ostracod transfer function}

The application of the WMAT (Root Mean Square Error $=0.23$ and the Bootstrapped $\left.R^{2}=0.84\right)$ to the fossil species data recorded in core BL01 (Fig. 5) shows two distinct periods where $\log _{10}$ (TDS) has varied in the lake. Prior to $5.2 \mathrm{ka}$ the modelled salinity of Blue Lake is higher than the later period. The average salinity during the early history was about $1 \mathrm{~g} / \mathrm{L}\left(10^{3} \mathrm{mg} / \mathrm{L}\right)$. However, relatively rapid excursions occurred with both lower $\left(0.2 \mathrm{~g} / \mathrm{L}\right.$ ) and higher salinities (up to $2.7 \mathrm{~g} / \mathrm{L}-10^{3.43} \mathrm{mg} / \mathrm{L}$ ) recorded. After $5.2 \mathrm{ka}$, the modelled salinity is lower, fluctuating between 0.2 and $0.37 \mathrm{~g} / \mathrm{L}$, although slightly higher salinity (0.73 to 


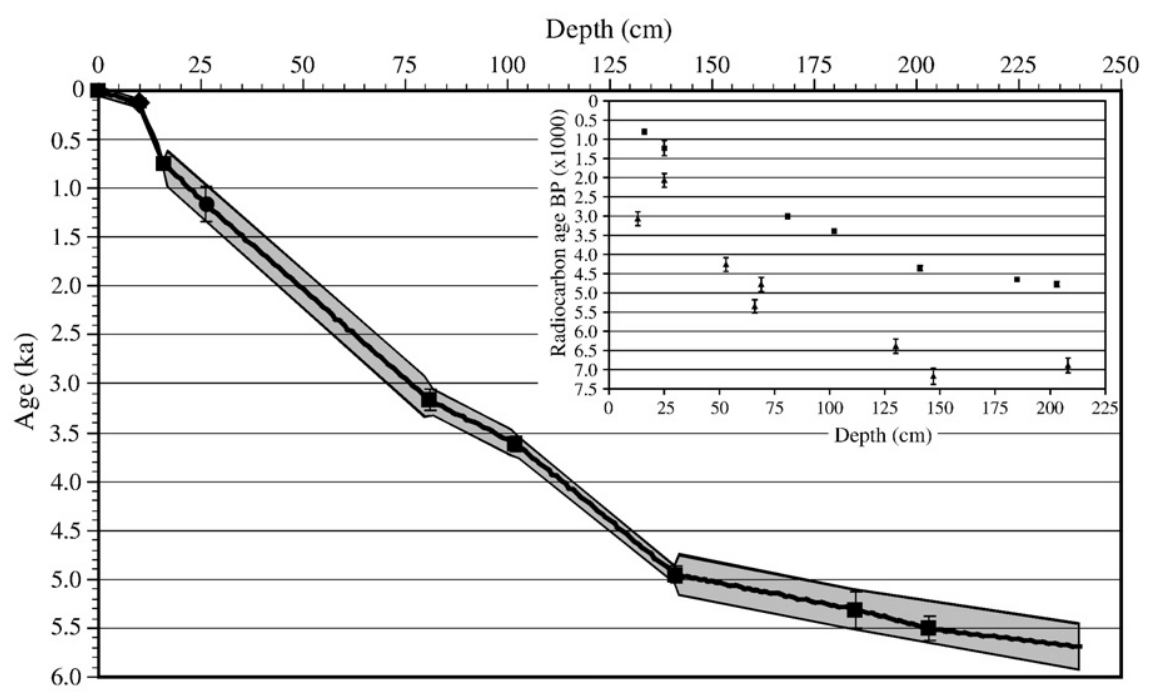

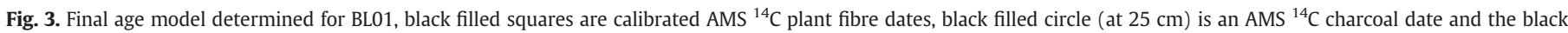

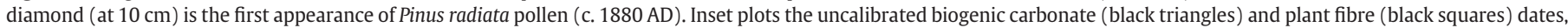
showing the variability in the lacustrine ${ }^{14} \mathrm{C}$ reservoir over time.

$1.16 \mathrm{~g} / \mathrm{L}$ ) is recorded for short periods. During the period of European settlement and extraction of water from Blue Lake, the salinity has risen to the present salinity value of $0.37 \mathrm{~g} / \mathrm{L}$. This period records rapid, smallscale fluctuations in salinity, and may reflect variations in the rate of pumping from the lake.

\subsection{Geochemistry}

\subsection{1. $\mathrm{Mg} / \mathrm{Ca}$}

The $\mathrm{Mg} / \mathrm{Ca}_{\text {valve }}$ data for $\mathrm{G}$. australica ranged from $1.12 \times 10^{-3}$ to $1.18 \times 10^{-2}$ with an average of $6.79 \times 10^{-3}$ (with one outlier at $135.6 \mathrm{~cm}$ (4.8 ka) removed); for C. novaezelandiae $\mathrm{Mg} / \mathrm{Ca}_{\text {valve }}$ ranged from $6.1 \times 10^{-4}$ to $1.12 \times 10^{-2}$, averaging $7.8 \times 10^{-3}$; I. smaragdinus ranged from $6.1 \times 10^{-3}$ to $1.15 \times 10^{-3}$ averaging $8.66 \times 10^{-3}$; L. mowbrayensis ranged from $2.43 \times 10^{-3}$ to $1.03 \times 10^{-3}$ averaging $6.2 \times 10^{-3}$; and there are two analyses of $L$. dorsosicula, 5.98 and $6.58 \times 10^{-3}$ and (Fig. 5).

\subsection{2. $\mathrm{Sr} / \mathrm{Ca}$}

The $\mathrm{Sr} / \mathrm{Ca}_{\text {valve }}$ for $\mathrm{G}$. australica ranges from $1.0 \times 10^{-5}$ to $8.2 \times 10^{-4}$ (mean $=5.6 \times 10^{-4} \pm 2.0 \times 10^{-4}, \mathrm{n}=37$ ) before $4.0 \mathrm{ka}$, and after $4.0 \mathrm{ka}$ G. australica $\mathrm{Sr} / \mathrm{Ca}_{\mathrm{valve}}$ range from $7.7 \times 10^{-4}$ to $1.12 \times 10^{-3}$ (mean $=9.1 \times 10^{-4} \pm 7 \times 10^{-5}, \mathrm{n}=76$ with one outlier removed). The small number of analyses of $C$. novaezelandiae before $(\mathrm{n}=5)$ and after $(\mathrm{n}=3) 4.0 \mathrm{ka}$ have mean $\mathrm{Sr} / \mathrm{Ca}_{\text {valve }}$ of $6.8 \times 10^{-4} \pm 1.0 \times 10^{-4}$ and $1.1 \times 10^{-3} \pm 2.5 \times 10^{-4}$, respectively (Fig. 5). The $\mathrm{Sr} / \mathrm{Ca}_{\text {valve }}$ of analysed I. smaragdinus between 5.3 and $5.7 \mathrm{ka}$ of core BL01 had a mean of $9.4 \times 10^{-4} \pm 2.4 \times 10^{-4}(\mathrm{n}=15)$ and ranged from $5.1 \times 10^{-4}$ to $1.27 \times 10^{-3}$. The $\mathrm{Sr} / \mathrm{Ca}_{\text {valve }}$ for I. smaragdinus linearly decreases up the core.

Only two analyses of $L$. dorsosicula were performed (approximate age of $5.7 \mathrm{ka}$ ), and nine L. mowbrayensis analyses from sediments older than $4.0 \mathrm{ka}$ with $\mathrm{Sr} / \mathrm{Ca}_{\text {valve }}$ ranging from 4.63 to $6.46 \times 10^{-3}$ $\left(\right.$ mean $\left.=5.6 \times 10^{-3} \pm 5.4 \times 10^{-4}\right)$. Seven analyses of $\mathrm{Sr} / \mathrm{Ca}_{\mathrm{valve}}$ for L. mowbrayensis between $0.27 \mathrm{ka}$ and the present ranged from 1.8 to $2.3 \times 10^{-3}\left(\right.$ mean $\left.=2.1 \times 10^{-3} \pm 1.7 \times 10^{-4}\right)$.

\subsection{3. $\mathrm{Na} / \mathrm{Ca}$}

$\mathrm{The} \mathrm{Na} / \mathrm{Ca}_{\text {valve }}$ analysis performed on fossil ostracod valves in core BL01 show high variability prior to $4.0 \mathrm{ka}$ and low variability after $4.0 \mathrm{ka}$. From $5.4 \mathrm{ka}$ to $4.0 \mathrm{ka}$, G. australica was analysed for $\mathrm{Na} / \mathrm{Ca}_{\text {valve }}$ with a mean and standard deviation of $5.5 \times 10^{-3} \pm 5.4 \times 10^{-3}$ $(\mathrm{n}=36)$ reflecting the high intra-species variability in this section. Large inter-species $\mathrm{Na} / \mathrm{Ca}_{\text {valve }}$ variation occurs within the same horizon, for example, at $5.7 \mathrm{ka}$, the $\mathrm{Na} / \mathrm{Ca}_{\mathrm{valve}}$ of I. smaragdinus was $1.02 \times 10^{-2}$. The mean $\mathrm{Na} / \mathrm{Ca}_{\text {valve }}$ of $64 \mathrm{G}$. australica analyses between 4.0 and $0.53 \mathrm{ka}$ is significantly lower than the previous period (mean $=1.8 \times 10^{-4} \pm 1.5 \times 10^{-4}$, using the Smith-Satterthwaite Test, where $\mathrm{t}=5.91, \mathrm{df}=35, \alpha=0.05, \mathrm{p}<0.001$ ) to the earlier period. Similarly, after $0.53 \mathrm{ka}$ the $\mathrm{Na} / \mathrm{Ca}_{\text {valve }}$ of the $\mathrm{G}$. australica analyses increases significantly (mean $=1.46 \times 10^{-3} \pm 3.0 \times 10^{-4}$, using the Smith-Satterthwaite Test, where $\mathrm{t}=14.4, \mathrm{df}=14.3, \alpha=0.05$, $\mathrm{p}<0.001$ ). These trends are clearly evident in Fig. 5 .

\subsection{4. $\delta^{18} \mathrm{O}$}

In total 115 stable isotope analyses were performed on ostracod valves recovered from the BL01 core. Seven horizons from core BL01 were analysed for $G$. australica and $C$. novaezelandiae, and a relatively constant $\delta^{18} \mathrm{O}$ offset of $+0.76 \pm 0.27 \%$ o for the latter. Two horizons were analysed for $\delta^{18} \mathrm{O}$ of $G$. australica and I. smaragdinus resulting in an offset of $+0.39 \pm 0.02 \%$ o for I. smaragdinus compared to $G$. australica. This results in a $G$. australica-calibrated $\delta^{18} \mathrm{O}$ profile $\left(\delta^{18} \mathrm{O}_{\text {norm }}\right)$, where $0.76 \%$ was subtracted from $C$. novaezelandiae $\delta^{18} \mathrm{O}$ values and $0.39 \%$ subtracted from $I$. smaragdinus $\delta^{18} \mathrm{O}$ values, but note that this only applies to two samples. Unfortunately, too few samples were available. In addition, Blue Lake does not have any equivalent in the Australian landscape today as most crater lakes in southern Australia are saline and do not share a similar history of lake level changes.

Using the $\delta^{18} \mathrm{O}_{\text {norm }}$ data, the period from 5.7 to $5.0 \mathrm{ka}$ is a period of steep increase in $\delta^{18} \mathrm{O}_{\text {norm }}$ from $-2.47 \%$ o to $+0.62 \%$. The following period from 5.0 to 0.44 ka represents a gradual increase in $\delta^{18} \mathrm{O}_{\text {norm }}$ rising from $+0.9 \%$ o to $+2.9 \%$. From 0.44 ka to the present, there has been a precipitous decrease in $\delta^{18} \mathrm{O}_{\text {norm }}$ from $+2.9 \%$ 。 to $+1.85 \%$ 。 (Fig. 5).

\subsection{5. $\delta^{13} \mathrm{C}$}

Comparing the $\delta^{13} \mathrm{C}$ of $\mathrm{G}$. australica with $C$. novaezelandiae and $I$. smaragdinus from the same horizons recorded higher $\delta^{13} \mathrm{C}$ in the latter species with an average offset of $3.48 \pm 0.45 \%$ ond $3.28 \pm 0.53 \%$, respectively. This results in a G. australica-calibrated $\delta^{13} \mathrm{C}$ profile $\left(\delta^{13} \mathrm{C}_{\text {norm }}\right)$ following the similar subtraction of these $\delta^{13} \mathrm{C}$ values from the ostracods similar to the $\delta^{18} \mathrm{O}$ measurements. Similarly to our comments on the disparity of $\delta^{18} \mathrm{O}$ values for the three species, the $\delta^{13} \mathrm{C}$ comparison has to be treated with caution, but it only concerns the lower part of the core. Even if the adjustment towards a common $\delta^{13} \mathrm{C}$ signal is inadequate, the observed trend is still prevalent. 


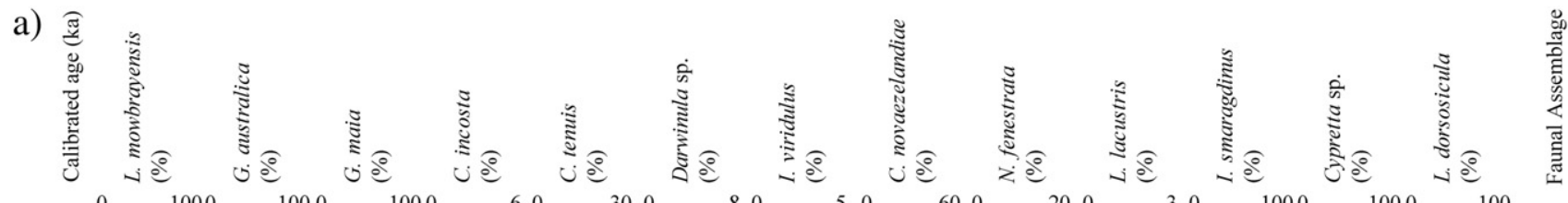

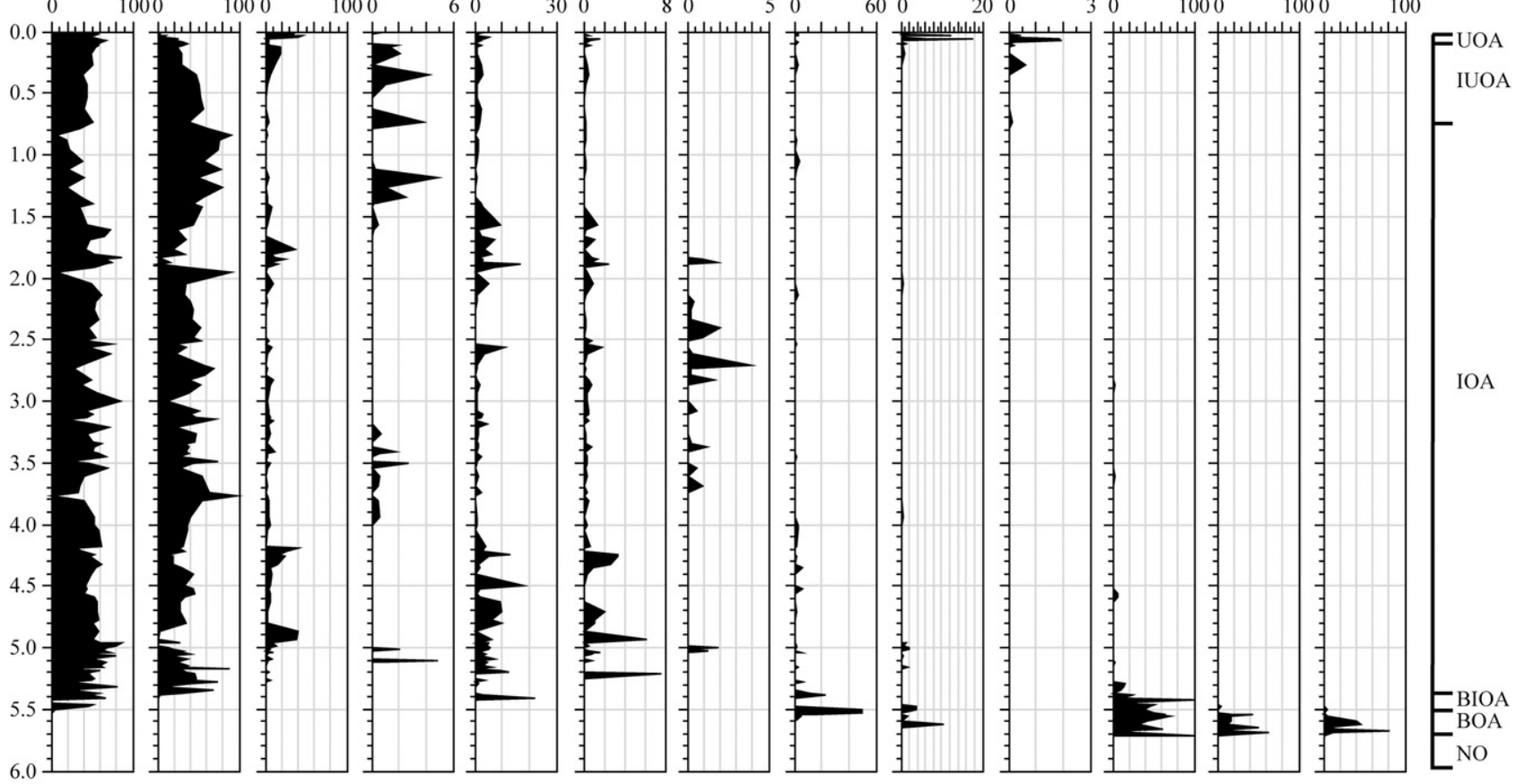

b)

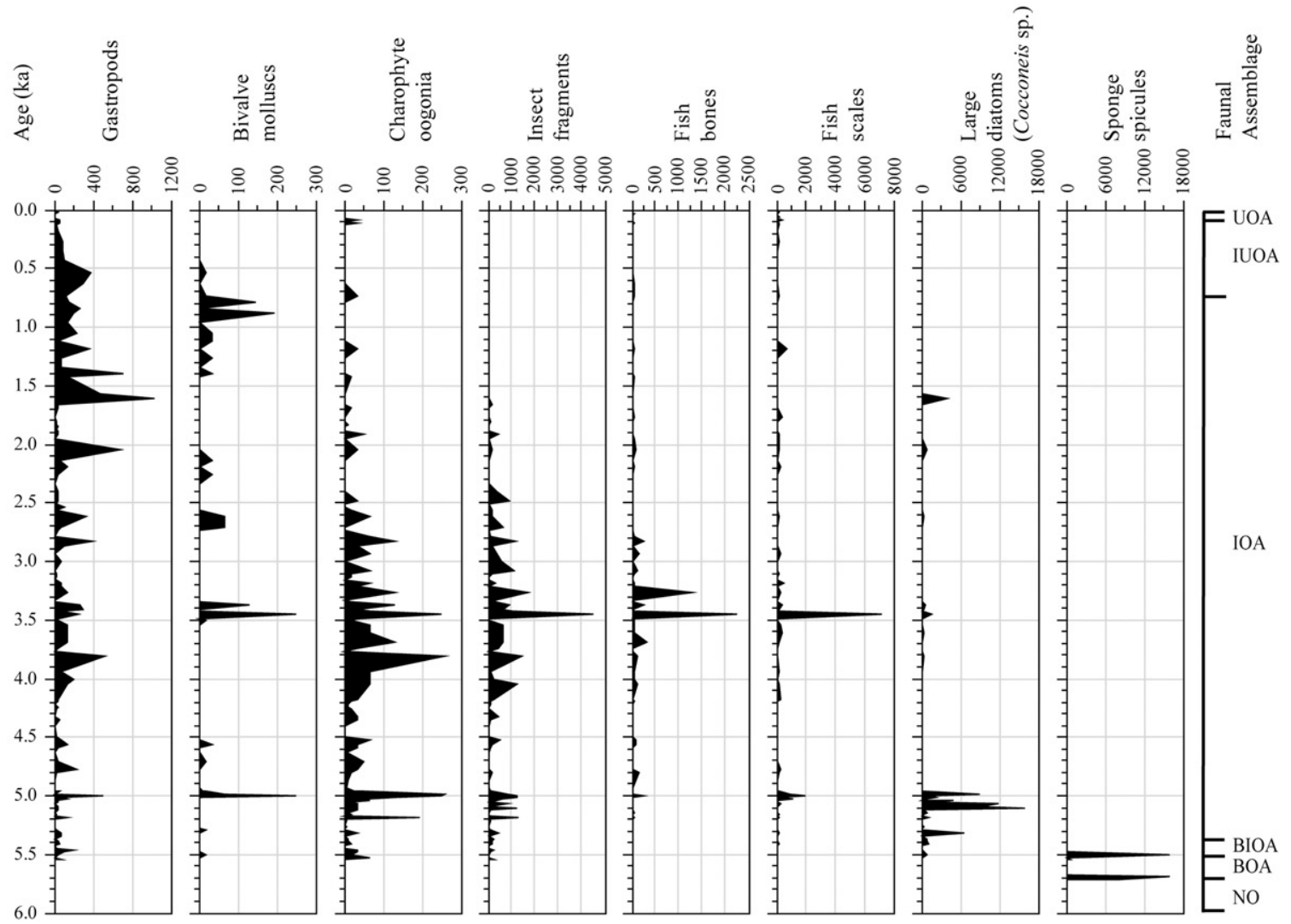

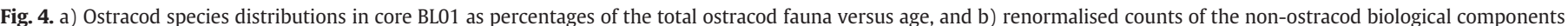

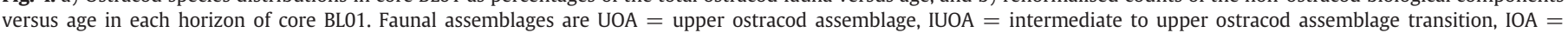
intermediate ostracod assemblage, $\mathrm{BIOA}=$ basal to intermediate ostracod assemblage transition, $\mathrm{BOA}=$ basal ostracod assemblage and $\mathrm{NO}=$ no ostracods. 


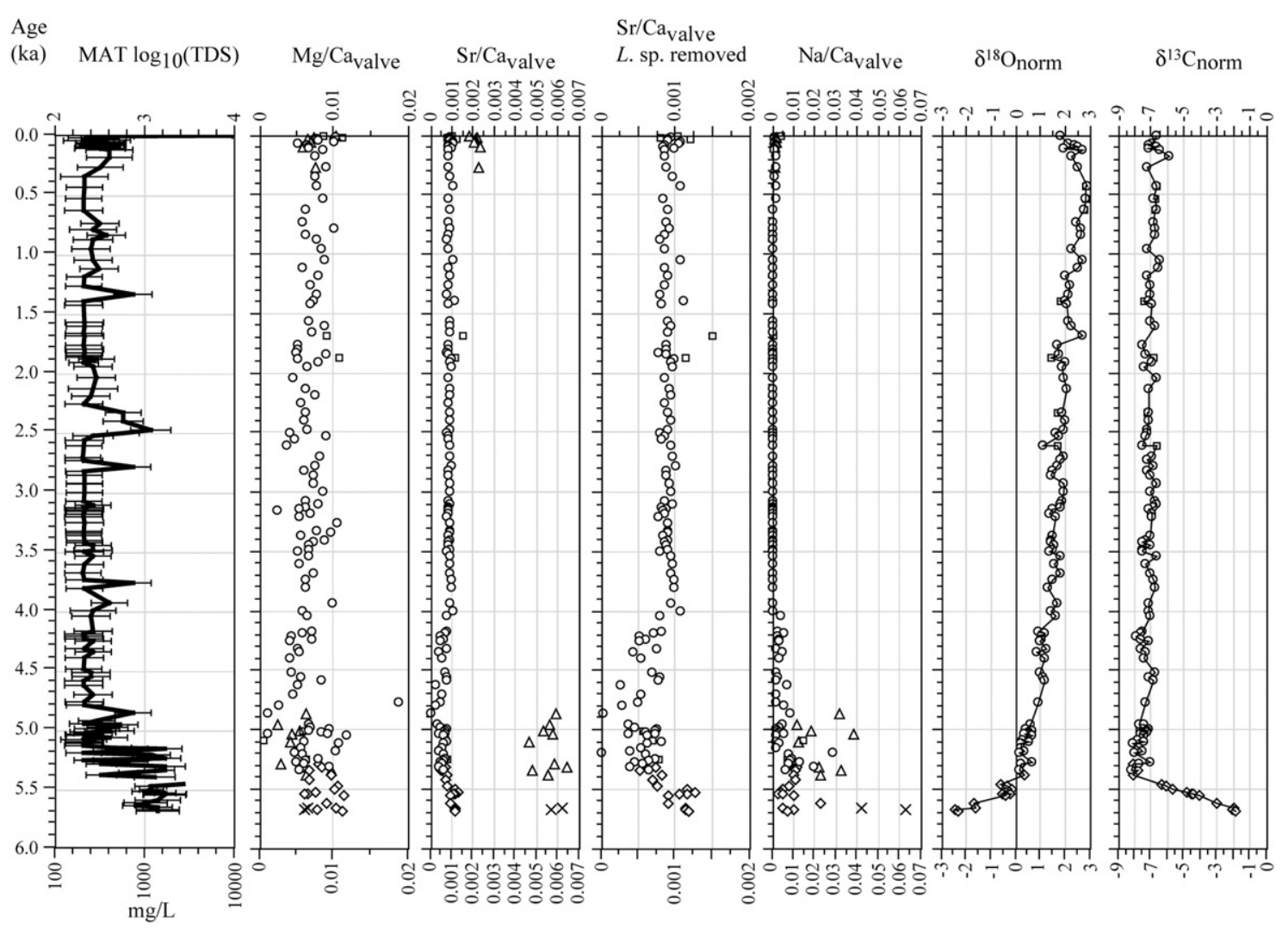

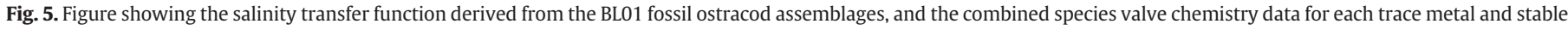

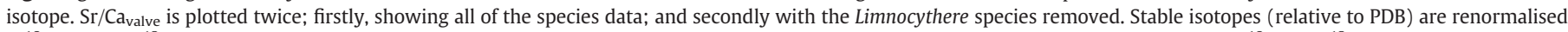

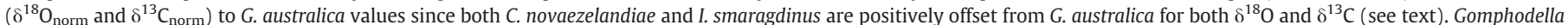
australica (circles), Ilyodromus viridulus (diamonds), Candonocypris novaezelandiae (squares), Limnocythere dorsosicula (crosses) and Limnocythere mowbrayensis (triangles).

From 5.7 to about $5.4 \mathrm{ka}$, there is a dramatic decrease in $\delta^{13} \mathrm{C}_{\text {norm }}$ from $-1.84 \%$ o to $-8.16 \%$. From 5.4 to $1.8 \mathrm{ka}$, there is a gradual linear increase in $\delta^{13} C_{\text {norm }}$ from about $-8 \%$ to $-6.5 \%$. Superimposed on this linear increase is an approximate 900 year cycle with increases and decreases of $\delta^{13} \mathrm{C}_{\text {norm }}$ of $1.5 \%$. After $1.8 \mathrm{ka}$, the cycle is not apparent (Fig. 5).

\subsection{Hydrochemical and lake level modelling}

As shown in the hydrochemical modelling of modern Blue Lake waters and comparison with the sedimentary profile recovered from core BL01 and the historical measured lake level (see Supplementary Information - see Palaeogeography, Palaeoclimatology, Palaeoecology website), the saturation state of calcite and the profiles of $\mathrm{Mg} / \mathrm{Ca}_{\text {water }}$ in Blue Lake are intimately related.

Extrapolation of these relationships to the longer term record preserved in Blue Lake implies that significant lowering of lake level will result in a deepening of the saturation index of calcite chemocline and the summer $\mathrm{Mg} / \mathrm{Ca}_{\text {water }}$ chemocline. This means that calcite will have a higher state of saturation, i.e. higher likelihood of precipitating at greater water depth, because of warmer water temperatures and higher activities of $\mathrm{Ca}^{2+}$ and $\mathrm{HCO}_{3}^{-}$in the water column. Decreasing the depth of the lake will also result in longer periods of holomixis allowing overturn of the water column and prolonged periods of elevated calcite saturation. This subsequently will raise the $\mathrm{Mg} / \mathrm{Ca}_{\text {water }}$, and with longer periods of overturning, increase the $\mathrm{Mg} / \mathrm{Ca}_{\text {water }}$ available to benthic ostracods during their valve formation.

Assuming that the $\mathrm{Mg} / \mathrm{Ca}_{\text {valve }}$ of $\mathrm{G}$. australica is representative of the horizon sampled and that the mean age attributed to those horizons is correct, then conversion of these ages to calendar years allows comparison of the $\mathrm{Mg} / \mathrm{Ca}_{\text {valve }}$ of those horizons to the mean measured lake level (metres Australian Height Datum - mAHD) at that time
(Fig. 6). Fig. 7 shows a significant $(r=-0.8, p<0.05)$ negative linear relationship between mean lake level ( $\mathrm{m} \mathrm{AHD}$ ) and the $\mathrm{Mg} / \mathrm{Ca}_{\text {valve }}$ of the benthic G. australica.

Consequently, this $\mathrm{Mg} / \mathrm{Ca}_{\text {valve }}$ versus lake water depth relationship can be extrapolated to model the pre- 1880 water depth of Blue Lake, at least for the period when Blue Lake had attained a steady hydrochemical state (i.e. post-4 ka). The resulting palaeo-lake level curve is shown in Fig. 8.

\section{Discussion}

\subsection{Sedimentology and geochronology}

Examination of Fig. 3 shows that the early section of the record, prior to about 5.0 ka registered very rapid sedimentation rate and, after $5.0 \mathrm{ka}$, the sedimentation rate slowed. The sedimentation rate was slowest between 0.75 and $0.13 \mathrm{ka}$, but rapidly increased during the period of European settlement of the area.

The Brown Clay Facies (see Supplementary information) lacks primary biogenic carbonate or organic plant fibres, so no ${ }^{14} \mathrm{C}$ dates could be obtained from this section of core BL01. Glasgow (pers. comm.) identified Tertiary pollen in this section, which originated from the Miocene limestone bedrock. Optical Stimulated Luminescence dating of the commonly occurring quartz grains is one means of resolving the dating ambiguities in the lower facies.

Leaney et al. (1995) described three Mackereth cores from Blue Lake and identified two broad sedimentolgical facies, a laminated facies and a uniform dark coloured facies, and identified the boundary between these two facies at 200,288 and $263 \mathrm{~cm}$, respectively. This boundary corresponds to the boundary at $242.5 \mathrm{~cm}$ separating the Brown Clay Facies and Sub-Facies 1A of the Moderately Laminated Facies (Table S1, 


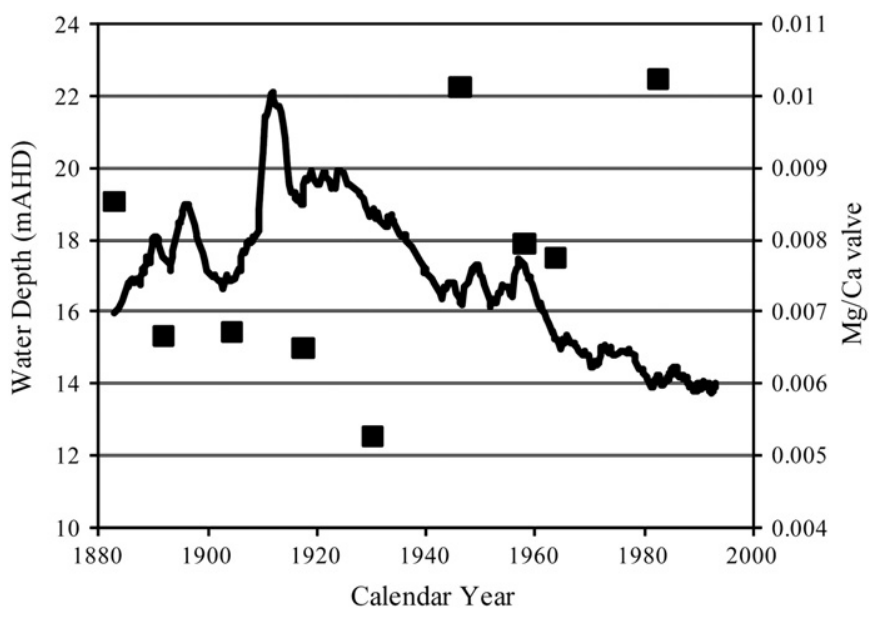

Fig. 6. Blue Lake water depth (mAHD - D.W.L.B.C., 2010) (solid line) and the $\mathrm{Mg} / \mathrm{Ca}_{\mathrm{valve}}$ (black squares) with respect to date of sampling. This assumes that the mean age of the age model converted to calendar age, and using this as an exact date for comparison with the water depth measured at the pontoon shows a significant negative correlation (see Fig. 7).

see Supplementary information - see Palaeogeography, Palaeoclimatology, Palaeoecology website).

The Moderately Laminated Facies ( 242.5 to $12.3 \mathrm{~cm}$ depth) spans the entire middle to late Holocene record recovered from core BL01. The lowest calibrated AMS ${ }^{14} \mathrm{C}$ date was obtained from $203 \mathrm{~cm}(5.5 \mathrm{ka})$ and the age model has been extrapolated down to the Brown Clay Facies boundary. The seven calibrated AMS ${ }^{14} \mathrm{C}$ dates recovered from the upper facies provide a well defined chronologic history for this record.

The Densely Laminated Facies begins at $12.3 \mathrm{~cm}$ (c. $0.35 \mathrm{ka}$ ) in core BL01 with the latter part being deposited after European settlement of the Mount Gambier district in 1839 (http://www.mountgambiertourism.com.au/, 2007). No AMS ${ }^{14} \mathrm{C}$ dates were obtained from this section, however, the presence of $P$. radiata at $10 \mathrm{~cm}$ depth constrains the age at approximately 125 years before coring (http://www.mountgambiertourism.com.au/, 2007). The top of the core is assumed to be the present day sediment-water interface.

The discrepancy between the organic ${ }^{14} \mathrm{C}$ ages and biogenic carbonate ages in the Blue Lake sediment is consistent with observations of the regional groundwater (Love et al., 1994), and supports the notion of a variable lacustrine radiocarbon reservoir in Blue Lake. Reservoir ages calculated from modelled ages (using linear interpolation and squared errors between dates) vary between 800 to $2800{ }^{14} \mathrm{C}$ years. There is no significant difference between the reservoir ages obtained from comparisons of organic dates with pure ostracod calcite or with mixed biogenic carbonate (i.e. ostracods and juvenile gastropods). No dates were obtained from inorganic calcite, and relict foraminifera were also avoided, of which both sources could provide erroneously old ages. The age of the modern water sample $\left(2385 \pm 30{ }^{14} \mathrm{C} \mathrm{yr} \mathrm{BP}\right)$ is also

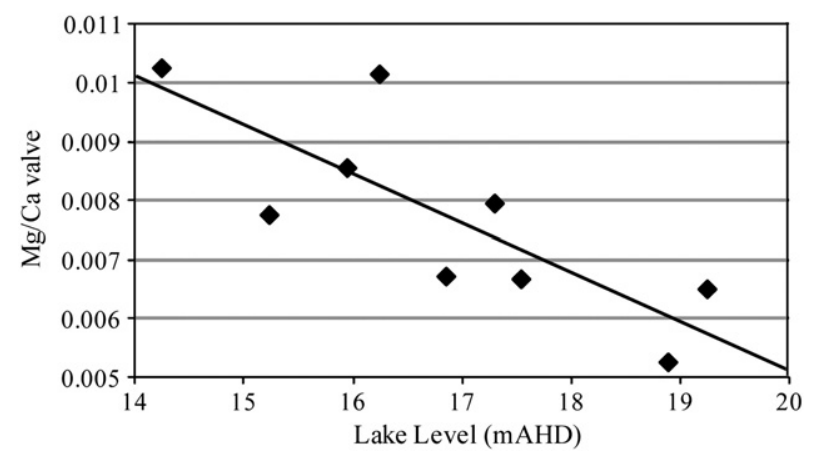

Fig. 7. Plot of $\mathrm{Mg} / \mathrm{Ca}_{\mathrm{valve}}$ of $\mathrm{G}$. australica versus Lake Level (mAHD), showing the significant negative correlation between the two variables.

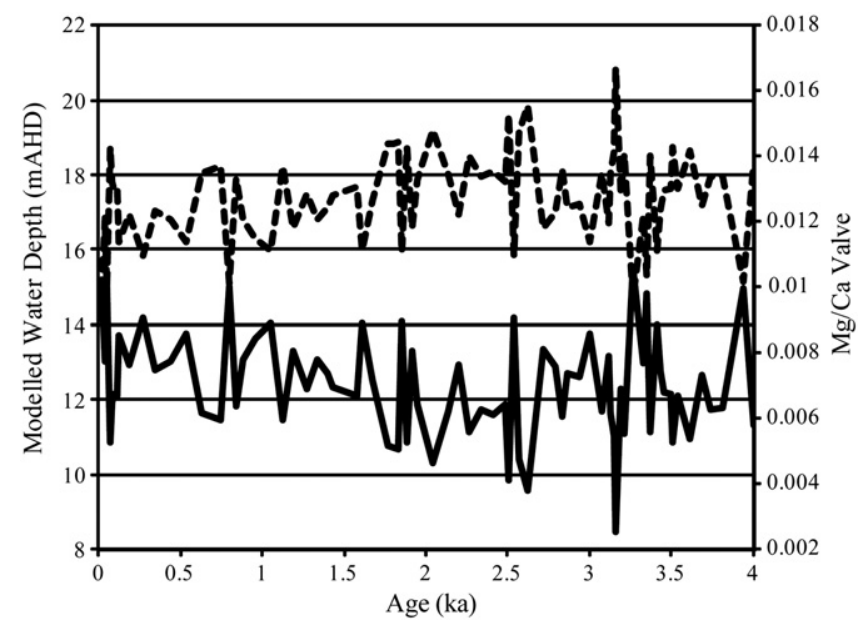

Fig. 8. Comparison of the modelled lake water depth (mAHD - dashed line) versus benthic $\mathrm{Mg} / \mathrm{Ca}_{\text {valve }}$ (solid line) for the last $4 \mathrm{ka}$.

consistent with the range, so we can be confident that our calculated range is a reflection of reservoir ages in Blue Lake during the mid to late Holocene.

Leaney et al. (1995) obtained bulk carbonate ${ }^{14} \mathrm{C}$ ages from their cores. However, due to the fact that their samples contain a mixture of biogenic and inorganic carbonates and they do not adequately account for the significant (and variable) lacustrine reservoir effect, it is difficult to reconcile their ages with the age model presented here. We also believe that by the use of bulk samples, Leaney et al. (1995) would have been dating the reworked Tertiary foraminifera that abound in the lake sediments, having been weathered out of the Mount Gambier Limestone. The incorporation of radiocarbon-dead Tertiary foraminifera would result in erroneously old ages for the date of sediment deposition. As such, we propose that our age model (based only on AMS ${ }^{14} \mathrm{C}$ dates of organic macrofossils and the Pinus horizon) is a more accurate reflection of the age of the laminated portion of the Blue Lake sediment profile.

\subsection{Ostracod valve chemistry}

\subsection{1. $\mathrm{Mg} / \mathrm{Ca}_{\text {valve }}$ and lake level modelling}

Comparison of the modelled lake level curve ( $m$ AHD) to the measured $\mathrm{Mg} / \mathrm{Ca}_{\text {valve }}$ and the measured water level fluctuations at Blue Lake shows that the calculated water depth underestimates the highest measured water level by approximately $2.5 \mathrm{~m}$, but corresponds well with the lower end of the measured water levels (Fig. 9). This suggests that the variation in the water level in the relatively hydrologically stable post 4 ka period may be as high as 8 to $9 \mathrm{~m}$ rather than the 6 metres predicted here.

Interestingly, this period shows little variability in $\mathrm{Sr} / \mathrm{Ca}$ and $\mathrm{Na} / \mathrm{Ca}$ ratios. There is no significant relationship between measured lake level and the other chemical elements or transfer function modelled salinity.

Prior to $4 \mathrm{ka}$, the lake had not reached the stable hydrological state as it had after $4 \mathrm{ka}$, evidenced by the highly variable $\mathrm{Sr} / \mathrm{Ca}_{\text {valve }}$ and $\mathrm{Na} / \mathrm{Ca}_{\mathrm{valve}}$, and as such the modelling of the lake level could not be applied to this earlier lacustrine phase.

\subsection{2. $\mathrm{Sr} / \mathrm{Ca}_{\text {valve }}$}

The discrepancy between the $\mathrm{Sr} / \mathrm{Ca}_{\mathrm{valve}}$ of the Limnocythere species and the other species examined in this core is the result of the Limnocythere species living in very different hydrological environments. The two alternatives, that there was detrital carbonate material contaminating the analysed Limnocythere specimens, or that analysis of multiple Limnocythere valves introduced errors into the results are disregarded as only pristine specimens were used for analysis, and that 


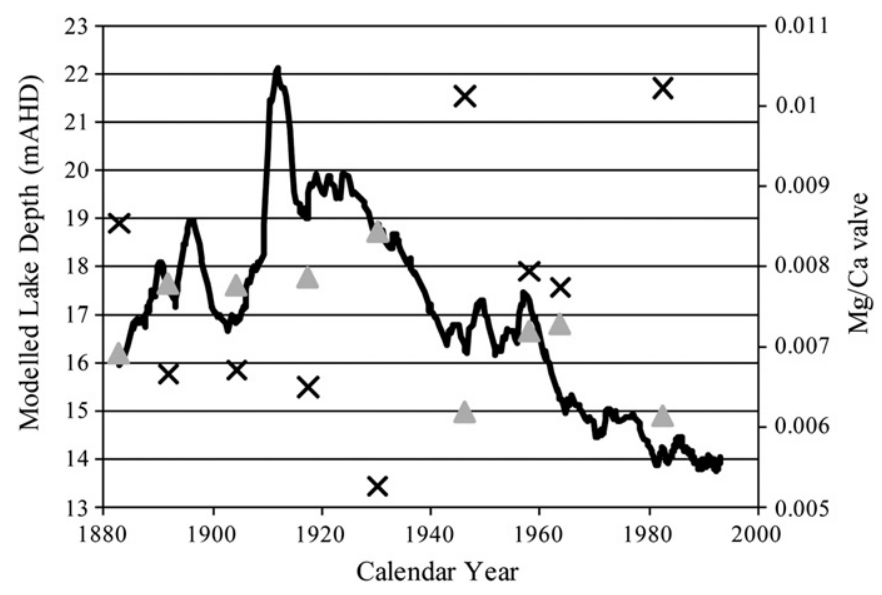

Fig. 9. Plot of the $\mathrm{Mg} / \mathrm{Ca}_{\text {valve }}$ (black crosses), the historically measured water depth (mAHD - solid black line) and the modelled water depth (mAHD - grey triangles) for the historical period of Blue Lake.

other chemical analyses recorded no such variation. For this reason, the $L$. mowbrayensis and $L$. dorsosicula analyses are not used in the reconstructions discussed below.

The $\mathrm{Sr} / \mathrm{Ca}_{\text {valve }}$ profile derived from benthic G. australica valves is a reflection of the bottom water $\mathrm{Sr} / \mathrm{Ca}_{\text {water }}$ conditions in Blue Lake. Prior to $4 \mathrm{ka}$, the water was shallow and eutrophic (see $\delta^{13} \mathrm{C}_{\mathrm{norm}}$ Section 6.2.5), but buffered against $\mathrm{pH}$ due to the contribution of $\mathrm{Ca}^{2+}$ and $\mathrm{HCO}_{3}^{-}$-rich groundwater sources from both the Dilwyn and Gambier aquifers. The elevated $\mathrm{HCO}_{3}^{-}$concentration hindered the uptake of $\mathrm{Sr}$ into the ostracod valve calcite (Gouramanis and De Deckker, 2010).

After $4 \mathrm{ka}$, when the lake had filled substantially and had reached a hydrological steady state with relatively constant contribution of $\mathrm{Ca}^{2+}$ and $\mathrm{HCO}_{3}^{-}$from both aquifers, the $\mathrm{Sr} / \mathrm{Ca}_{\text {valve }}$ became relatively invariant. The hydrochemical modelling of the modern Blue Lake water (see Supplementary information Fig. S8) records relatively invariant $\mathrm{Ca}^{2+} / \mathrm{HCO}_{3}^{-}$throughout the water column in 1993 and 1994. Subtle variations record a slight decline in $\mathrm{Ca}^{2+} / \mathrm{HCO}_{3}^{-}$in the upper water column and a slight increase in $\mathrm{Ca}^{2+} / \mathrm{HCO}_{3}^{-}$in the lower water column reflecting the $\mathrm{HCO}_{3}^{-}$buffered nature of the water column.

\subsection{3. $\mathrm{Na} / \mathrm{Ca}_{\text {valve }}$}

The salinity $\left(\mathrm{TDS}_{\mathrm{DIL}}\right)$ and $\mathrm{Na} / \mathrm{Ca}_{\text {water }}\left(\mathrm{Na} / \mathrm{Ca}_{\mathrm{DIL}}\right)$ of the Dilwyn aquifer, are larger than the salinity $\left(\mathrm{TDS}_{\mathrm{GAM}}\right)$ and $\mathrm{Na} / \mathrm{Ca}_{\text {water }}\left(\mathrm{Na} / \mathrm{Ca}_{\mathrm{GAM}}\right)$ of the Gambier aquifer (Love et al., 1993). As such, variation in $\mathrm{Na} / \mathrm{Ca}_{\text {valve }}$ reflects variation in the contribution of the unconfined Gambier aquifer (lower $\mathrm{Na} / \mathrm{Ca}_{\text {valve }}$ ) and the confined Dilwyn aquifer (higher $\mathrm{Na} / \mathrm{Ca}_{\text {valve }}$ ) to Blue Lake water through time. Because of this, $\mathrm{Na} / \mathrm{Ca}_{\text {valve }}$ closely follows salinity, however, this does not suggest that $\mathrm{Na} / \mathrm{Ca}_{\text {valve }}$ is a salinity indicator in Blue Lake, but that it is an aquifer tracer through the Blue Lake core sequence.

The very similar values obtained from analyses of G. australica, I. smaragdinus and $C$. novaezelandiae from the same levels in the core suggests that these species take up $\mathrm{Na}$ in the same way from the water column. As $L$. mowbrayensis and $L$. dorsosicula have very different $\mathrm{Na} / \mathrm{Ca}_{\text {valve }}$ values to those of the other species from the same horizons, this indicates that these species live in a different habitat and, as such, will be ignored until better understanding of the $\mathrm{Na} / \mathrm{Ca}$ incorporation mechanism is gained.

\subsection{4. $\delta^{18} \mathrm{O}_{\text {norm }}$}

The $\delta^{18} \mathrm{O}_{\text {norm }}$ record of ostracod valves preserved in Blue Lake reflects a history of evaporative enrichment and fluctuating groundwater recharge. Love et al. (1993; 1994) showed that the modern groundwater around Blue Lake is significantly depleted in ${ }^{18} \mathrm{O}$ with the $\delta^{18} \mathrm{O}_{\text {water }}$ ranging from -3.5 to $-4.9 \%$. However, the general increase in the $\delta^{18} \mathrm{O}_{\text {norm }}$ record in the core indicates that ${ }^{18} \mathrm{O}$ enrichment was the trend in the $\delta^{18} \mathrm{O}_{\text {norm }}$ evolution.

The factors influencing ${ }^{18} \mathrm{O}$ fractionation between the $\delta^{18} \mathrm{O}_{\text {water }}$ and the $\delta^{18} \mathrm{O}_{\text {G.australica, }} \delta^{18} \mathrm{O}_{\text {I.smaragdinus }}$ and $\delta^{18} \mathrm{O}_{\text {C.novaezelandiae }}$ are unknown, as are the vital effects that each species imposes on the $\delta^{18} \mathrm{O}$ utilised during valve formation. Although we do not know the effect of each of these factors on the $\delta^{18} \mathrm{O}$ incorporation in valves for these species, the trend towards enrichment is not compromised as both fractionation differences between ostracod low-Mg calcite and inorganic precipitated low-Mg calcite results in $\delta^{18} \mathrm{O}$ enrichment in ostracod valves (Ito et al., 2003), and that, thus far, all vital offsets determined for the ostracods suggest that each species preferentially incorporates ${ }^{18} \mathrm{O}$ (Holmes and Chivas, 2002). Similarly, the thicker and larger valves that G. australica, I. smaragdinus and C. novaezelandiae calcify, and the calcification temperature, which has been measured to be $13.1{ }^{\circ} \mathrm{C}$ (Vanderzalm et al., 2009) in the hypolimnion where these species lived, would also act to enrich the valve calcite in $\delta^{18} \mathrm{O}$ (Ito et al., 2003). With all of these factors additively contributing to ostracod valve $\delta^{18} \mathrm{O}$ enrichment, this overall trend towards the $\delta^{18} \mathrm{O}_{\text {norm }}$ enrichment for the most part of the Blue Lake record is a true reflection of the $\delta^{18} \mathrm{O}_{\text {water. }}$. The combined total of these $\delta^{18} \mathrm{O}$ enrichment factors in ostracod valve calcite may be as high as several per mille (vital effects can be as high as $2.5 \pm 0.2 \%$ as recorded in Candona candida and Pseudocandona rostrata from the U.K. (Keatings et al., 2002), and the vital effects for the species examined from this core are unknown). However, until these vital effects are known from in vitro experimentation or detailed and careful field collection (e.g. von Grafenstein et al., 1999b), accurate $\delta^{18} \mathrm{O}_{\text {water }}$ reconstructions from Blue Lake fossil ostracods cannot be produced.

The initial low $\delta^{18} \mathrm{O}_{\text {norm }}$ in Blue Lake is the result of a shallow, possibly ephemeral waterbody, and, as the lake fills, there is a broad trend towards $\delta^{18} \mathrm{O}_{\text {norm }}$ increase with an initial rapid ${ }^{18} \mathrm{O}$ enrichment during the middle Holocene ( 5.7 to $5.4 \mathrm{ka}$ ). This rate of enrichment gradually slows as the lake is filled by inflowing ${ }^{18} \mathrm{O}$-depleted groundwater until about 200 years ago. Subtle variations in the $\delta^{18} \mathrm{O}_{\text {norm }}$ throughout this period reflect periods of increased groundwater recharge causing either subtle depletion or slowing of the enrichment rate. After $5.4 \mathrm{ka}$, periods of $\delta^{18} \mathrm{O}$ increase suggest periods of reduced groundwater inflow and precipitation, and increased drought with elevated temperatures causing evaporation to preferentially remove ${ }^{16} \mathrm{O}$ from the lake water (Gat, 1996).

Since European establishment of the Mount Gambier area, there has been a significant depletion in the $\delta^{18} \mathrm{O}_{\text {norm. }}$. This coincides with lake water extraction by pumping for the town's supply. This has lead to an increase in the rate of recharge of groundwater sources (Leaney et al., 1995; Herczeg et al., 2003).

\subsection{5. $\delta^{13} C_{\text {norm }}$ and chemical cyclicity}

The record of $\delta^{13} C_{\text {norm }}$ from core BL01 is unlike any of the other parameters analysed from the ostracod valves and will be treated here separately.

In the period from 5.7 to $5.4 \mathrm{ka}$, the ostracod valves show a significant trend towards decreased $\delta^{13} \mathrm{C}_{\text {norm }}$ (from -1.84 to $-8.16 \%$ ). This suggests that in this early phase of Blue Lake establishment, algal photosynthesis in the shallow lake would have initially maintained a relatively enriched $\delta^{13} \mathrm{C}_{\text {norm. }}$. However, with increased contribution of groundwater from both aquifers as the lake filled, $\delta^{13} \mathrm{C}_{\text {norm }}$ decreases to $-8.3 \%$ approaching the modern day $\delta{ }^{13} C_{\text {norm }}$ values of both aquifers $\left(-9.3 \%\right.$ ) (Love et al., 1993; 1994). Thus, the $\delta^{13} C_{\text {norm }}$ suggests a period of lake filling from groundwater sources.

Replotting the $\delta^{13} C_{\text {norm }}$ data of Fig. 5 from 5.4 ka to the Present in Fig. 10, and applying a five-point moving-average curve to the data show a series of cycles prior to $1.8 \mathrm{ka}$. The absolute $\delta^{13} \mathrm{C}_{\text {norm }}$ minima occur at c. 5.3, $4.2,3.5,2.5$ and $1.8 \mathrm{ka}$ and record a periodic pacing of $895 \pm 190$ years. At the present, it is unknown whether this periodicity is a real phenomenon or an artefact of this particular dataset. It is also unclear why this cyclical pattern ends at $1.8 \mathrm{ka}$. 


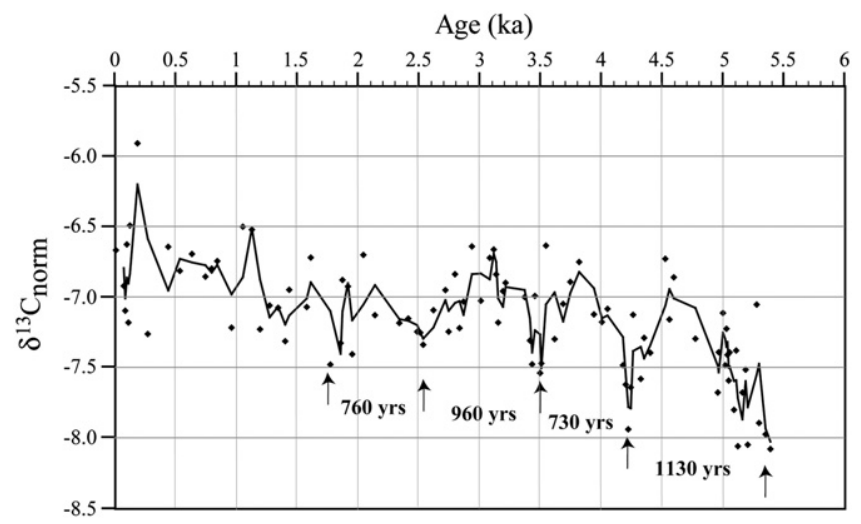

Fig. 10. Plot of the $\delta^{13} C_{\text {norm }}$ data determined from Blue Lake (core BL01) ostracods (I. smaragdinus and C. novaezelandiae renormalised to G. australica - see text) from $5.4 \mathrm{ka}$ to the present, fitted with a five-point moving-average curve. Arrows indicate the absolute minima in the $\delta^{13} \mathrm{C}_{\text {norm }}$ used in determining the periodicity in the record ( $895 \pm 187$ years), and ages between arrows indicate period between absolute minima. The difference between successive absolute minima was used to determine this periodicity.

Moros et al. (2009) identified a 1567 year periodicity in $\delta^{18} \mathrm{O}$ from benthic marine foraminifera recovered from Holocene sediments from the offshore Murray Canyons on the southeastern Australian continental margin. This cyclicity is interpreted as cold water pulses comparable to Antarctic and Northern Hemisphere records (see references in Moros et al., 2009). These authors identified these cold events as occurring at 5.8, 4.3, 2.7 and $1.4 \mathrm{ka}$ for the mid- to late Holocene in this region. The 4.3 and 2.7 ka events also occur in the $\delta^{13} C_{\text {norm }}$ record of Blue Lake (within $2 \sigma$ dating errors), which may be the result of lower productivity in the lake at these times caused by the lower ambient temperatures. As such, until more high-resolution palaeoclimate records from many regions are examined, local and global teleconnections of Holocene climate cyclicity will remain poorly understood.

\section{Blue Lake palaeohydrological history}

The palaeohydrological history of Blue Lake recorded in core BL01 has four distinct chronological periods distinguishable in the sedimentological, faunal and geochemical record.

\subsection{Before $5.9 \mathrm{ka}$}

Prior to $5.9 \mathrm{ka}$, other nearby records of palaeoenvironmental change from southeastern Australia (Dodson, 1974a,b; Bowler, 1981; De Deckker, 1982b; De Deckker et al., 1982; Edney et al., 1990; Colhoun et al., 1999; Stanley and De Deckker, 2002) show that the early to middle Holocene was a period of elevated lake levels in southeastern Australia due to increased regional precipitation. However, this period in Blue Lake (Brown Clay Facies), characterised by a uniform brown mud and a lack of fauna and plant fibres suggests that the full lacustrine phase had yet to be established.

Two possible hypotheses could account for this apparent discrepancy. Firstly, that the undated sediments could have formed prior to the mid-Holocene wet period. Glasgow (pers. comm.) identified Tertiary pollen eroded from the Miocene marine limestones of the crater wall and concentrated in the mud, however, due to the comparatively young ages of the volcanic crater, a much younger age for sediment deposition is envisaged. The sedimentary column from core BL01 does not preserve an unconformity, suggesting the alternative may have occurred.

The onset of deglaciation and early Holocene sea level rise of approximately $120 \mathrm{~m}$ (Lambeck and Chappell, 2001), flooded the $20 \mathrm{~km}$ wide continental shelf south of Blue Lake (Calvo et al., 2007; Moros et al., 2009). This sea level rise caused progradation of the intrusive oceanic wedge that restricted outflow from the Dilwyn and Gambier aquifers as the coastline receded. This contracted the aquifers landward of the coastline and causing vertical migration of the water table. The midHolocene wet phase across southeastern Australia was recharging the Dilwyn and Gambier aquifers and contributed to raising the water table. By $5.9 \mathrm{ka}$, the water table intersected with the Blue Lake volcanic crater and groundwater began to flow into the lake.

\subsection{9 to $4 \mathrm{ka}$}

The initial conditions of Blue Lake suggest a shallow lake that was significantly eutrophic, thus preventing the occurrence or preservation of ostracods prior to $5.7 \mathrm{ka}$. The presence of turbidites throughout this period indicates significant gravity flows down the crater slope. The cause of these turbidites may reflect tectonic activity or destabilisation of the crater walls as the water table rose.

As the water table is raised, the dominant contributor of groundwater initially is the Dilwyn aquifer, but this contribution wanes as increasing Gambier aquifer water flows into the lake. Fluctuations in the contribution of the Dilwyn and Gambier aquifers results in variable but decreasing modelled salinity, $\mathrm{Na} / \mathrm{Ca}_{\text {valve }}$ and $\delta^{13} \mathrm{C}_{\text {norm }}$ of the benthic ostracods (Fig. 5). The decline in the $\delta^{13} \mathrm{C}_{\text {norm }}$ indicates a trend from eutrophic conditions to oligotrophy and signifies a shift to the $\delta^{13} C_{\text {water }}$ of the aquifers (Love et al., 1993).

Talbot (1990) reported that over long periods of time ( $>5000$ years) lakes that have a strong positive $\delta^{18} \mathrm{O}$ and $\delta^{13} \mathrm{C}$ correlation are hydrologically closed systems. However, over shorter periods of time, this interpretation can be oversimplified due to subtle fluctuations in hydrology ( Li and Ku, 1997). Fig. 11 shows a strong negative correlation between $\delta^{18} \mathrm{O}_{\text {norm }}$ and $\delta^{13} \mathrm{C}_{\text {norm }}$ in this early period in Blue Lake indicating an uncoupling of the evolution of the $\delta^{18} \mathrm{O}_{\text {water }}$ and $\delta{ }^{13} \mathrm{C}_{\text {water }}$.

Today, the two aquifers have $\delta^{18} \mathrm{O}_{\text {water }}$ of -3.5 to $-4.9 \%$ ( Love et al., $1993 ; 1994)$. However, the significant enrichment in $\delta^{18} \mathrm{O}_{\text {water }}$ (reflected in the $\delta^{18} \mathrm{O}_{\text {norm }}$ ) must indicate a significant evaporative enrichment of the inflowing groundwater (Fig. 5). This $\delta^{18} \mathrm{O}_{\text {water }}$ enrichment initially proceeded rapidly, but the rate of enrichment slowed later in the record indicating that, as the lake deepened, the increased water volume buffered the temperature effect on the $\delta^{18} \mathrm{O}_{\text {water }}$.

This enrichment in $\delta^{18} \mathrm{O}_{\text {water }}$ can only be attributed to increased Evaporation/Precipitation (E/P) caused by an extensive arid period resulting in high evaporation as witnessed in other southeastern Australian lakes (Dodson, 1974a,b; Bowler, 1981; De Deckker, 1982b;

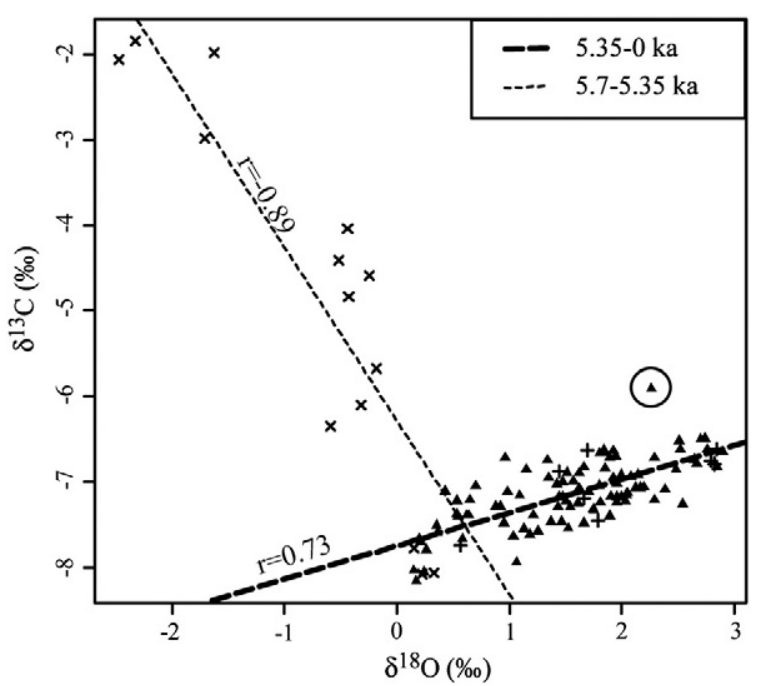

Fig. 11. Plot of $\delta^{18} \mathrm{O}_{\text {norm }}$ versus $\delta^{13} \mathrm{C}_{\text {norm }}$ with regressions plotted for periods from 5.7 to $5.35 \mathrm{ka}$ (thin dashed line) and from $5.35 \mathrm{ka}$ to present (thick dashed line). Filled triangles are analyses of G. australica, (X) represent analyses of I. smaragdinus, and (+) for $C$. novaezelandiae. Circled analysis is an apparent outlier and not included in the post-5.35 ka regression. 
D'Costa et al., 1989; Edney et al., 1990; Colhoun et al., 1999; Stanley and De Deckker, 2002; Gouramanis, 2009).

The early to middle Holocene stalagmite record from Lynds Cave in Tasmania suggested that the period from 6.6 to $5.1 \mathrm{ka}$ had the lowest precipitation and temperature (Xia et al., 2001). Lower sea surface temperatures (SST) (Calvo et al., 2007) and lower discharge from the nearby Murray River (Gingele et al., 2004; 2007) were also recorded in a marine core taken from offshore the Murray mouth, approximately $200 \mathrm{~km}$ west of Blue Lake, both reflecting increased aridity across southeastern Australia at this time.

Moros et al. (2009 and references therein) argue that a southward shift of the South Australian Frontal system that brought higher levels of precipitation through the early to mid-Holocene had retracted further south causing this reduction in rainfall.

In their review of global rapid climate change events, Mayewski et al. (2004) recognised the period from 4.2 to 3.8 ka from several of the 50 records they examined as a period of tropical aridity and cooling. However, these authors only included one record from New Zealand and none from Australia. McKenzie and Kershaw (1997) presented a pollen record from Chapple Vale, approximately $200 \mathrm{~km}$ east of Blue Lake, which showed a vegetation pattern shift from cool temperate rainforest to tall eucalypt forests from 5.2 to $4.1 \mathrm{ka}$ (calibrated using Stuiver and Reimer (1993) with the southern hemisphere dataset of McCormac et al. (2004)), caused by a decrease in precipitation and an increase in temperature. After $4.1 \mathrm{ka}$, the Chapple Vale record shows an increase in precipitation, similar to the Blue Lake data presented here.

\subsection{4 to $0.5 \mathrm{ka}$}

By $4 \mathrm{ka}$, the hydrological balance of Blue Lake had established a relatively stable system, dominated by groundwater recharge with lake levels responding to variations in E/P. This remained unchanged for nearly 3800 years.

The steady hydrological state is evident from the invariant $\mathrm{Sr} / \mathrm{Ca}_{\text {valve }}, \mathrm{Na} / \mathrm{Ca}_{\text {valve }}$ and modelled salinity reconstructions (Fig. 12).
For much of this period (prior to $0.5 \mathrm{ka}$ ) the groundwater recharge was almost exclusively from the Gambier aquifer. However, after $0.5 \mathrm{ka}$, the Dilwyn aquifer contributed up to $15 \%$ of the groundwater inflow to Blue Lake (Ramamurthy et al., 1985). The poor correlation between $\delta^{18} \mathrm{O}_{\text {norm }}$ and $\delta^{13} C_{\text {norm }}$ (Fig. 11), reflects a hydrologically open deep lake with low surface area (Talbot, 1990).

In this period, the permanently fresh, oligotrophic and deep (>60 $\mathrm{m}$ deep) Blue Lake records variations of up to 8 or $9 \mathrm{~m}$ in water depth (Figs. 8 and 9). These lake level changes occur rapidly and indicate that during this period the climate of southeastern Australia imposed a highly variable E/P on the regional hydrology.

Many other authors have suggested that this period across southeastern Australia was climatically highly variable, but, these studies lack the temporal sampling resolution to identify the subtle climate variability (Bowler and Hamada, 1971; Dodson, 1974a,b; De Deckker, 1982b; D'Costa et al., 1989; Edney et al., 1990; Leaney et al., 1995; Colhoun et al., 1999; Stanley and De Deckker, 2002).

\subsection{5 ka to present}

From $0.5 \mathrm{ka}$ to present, the $\delta^{18} \mathrm{O}_{\text {norm }}$ record shows a general trend towards decreased values, although, after approximately $1880 \mathrm{AD}$ minor fluctuations do occur. This decline in $\delta^{18} \mathrm{O}_{\text {norm }}$ is due to increased pumping and shortening of the residence time of the water in the lake (Ramamurthy et al., 1985; Herczeg et al., 2003). Herczeg et al. (2003) calculated the residence time of Blue Lake to have been $23 \pm 2$ years before 1850 , which has decreased to $8 \pm 2$ years today. Maintenance of the lake at relatively high levels when 10 to $15 \%$ of the volume is extracted for human use (Turner et al., 1984) is compensated for by elevated recharge from the two aquifers, including a higher proportion from the underlying Dilwyn aquifer. This is shown by an increase in the $\mathrm{Na} / \mathrm{Ca}_{\text {valve }}$ during this period. Relatively minor variations ( $<9$ m between 1880 and 1993) are due to variations in $\mathrm{E} / \mathrm{P}$, but the overall hydrological balance is controlled by groundwater recharge.

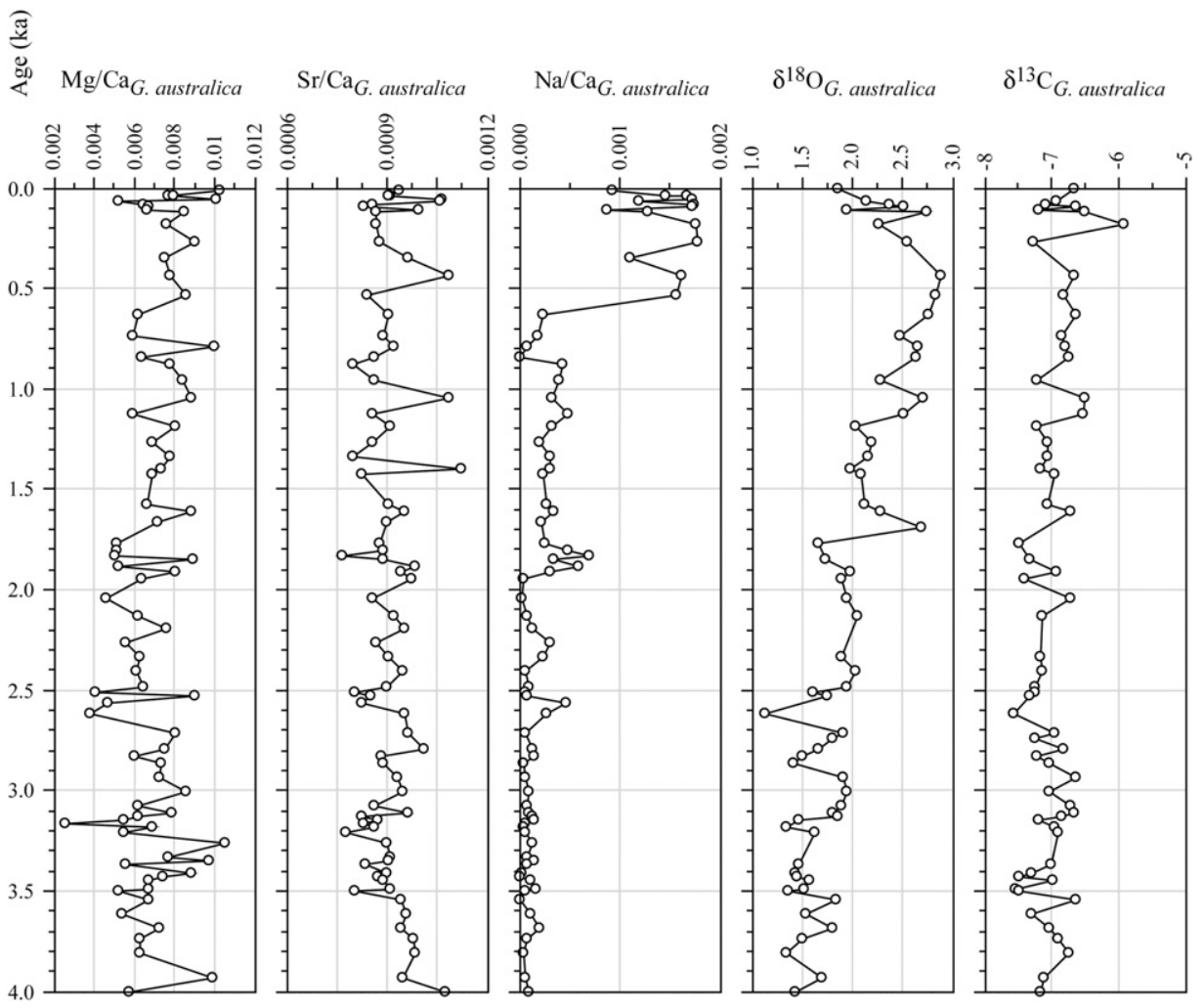

Fig. 12. Selected trace metal and stable isotope analyses of G. australica valves from 4 ka to the present from the core BL01. 
Herczeg et al. (2003) recorded a $3 \%$ decline in $\delta^{18} \mathrm{C}_{\text {carb }}$ and $\delta^{13} \mathrm{C}_{\text {org }}$ which they interpret to reflect a decrease in residence time of dissolved inorganic carbon in the lake. No apparent decline in $\delta^{13} \mathrm{C}_{\text {norm }}$ is observed from the benthic $G$. australica suggesting that the shift in $\delta^{13} \mathrm{C}$ recorded by Herczeg et al. (2003) is restricted to epilimnetic organic matter. Leaney et al. (1995) also showed a depletion in $\delta^{13} \mathrm{C}$ and $\delta^{18} \mathrm{O}$ caused by pumping of the lake. A future examination of the valve chemistry of the nektic ostracod $N$. fenestrata, may explain this discrepancy between G. australica $\delta^{13} C_{\text {norm }}$ and the stable isotope data of Leaney et al. (1995) and Herczeg et al. (2003).

The subtle variations in hydrology recorded in this section of Blue Lake and the subsequent reactions to increased pumping show that the hydrological balance in Blue Lake is closely linked to climate and anthropogenic use of the lake and surrounding catchment.

\section{Conclusion}

The ostracod valve chemistry record recovered from core BL01 from Blue Lake preserves a high-resolution sequence of environmental and hydrological change throughout the middle to late Holocene that can be related to climatic variation affecting the southeastern Australian region. The palaeoenvironmental and palaeoclimatic history of Blue Lake reflects a higher degree of variability in the climate system affecting southeastern Australia than had previously been documented from the area.

Prior to $5.9 \mathrm{ka}$, there was little water in the Blue Lake crater. This period coincides with the mid-Holocene wet phase recorded from cores examined from nearby lakes, indicating that the precipitation that fell on the Blue Lake catchment rapidly percolated through the crater floor and directly contributed to the underlying water table. Blue Lake, at this time, was little more than a very shallow, eutrophic lake, like the adjacent Brownes Lake today.

After $5.9 \mathrm{ka}$, the regional water table had risen sufficiently to intersect the crater and it began to fill with carbonate-saturated water. Ostracods became preserved in the sediment column by $5.7 \mathrm{ka}$. AMS ${ }^{14} \mathrm{C}$ dating of organic plant fibres and biogenic carbonate shows "old" water flowing into the lake. From 5.7 to 4 ka, the lake level rapidly rose, mirroring the rise in the water table, and a replacement of the waning Dilwyn aquifer's contribution to an increased Gambier aquifer contribution. This deepening of the lake resulted in a shift from eutrophic to oligotrophic conditions. However, as the lake level rose, the recharging groundwater was subjected to an arid climate (high $\mathrm{E} / \mathrm{P}$ ) resulting in the evaporative enrichment of the $\delta^{18} \mathrm{O}$ as shown by the ostracod valves composition.

By $4 \mathrm{ka}$, the lake had attained a sufficient depth so that the hydrological processes influencing the lake had reached a steady state.

In addition, soon after $4 \mathrm{ka}$ the hydrological processes operating at Blue Lake would have been very similar to the processes influencing the lake since monitoring of Blue Lake began (from approximately 1880). These processes include thermal stratification and lake level lowering due to evaporation from the lake surface during the warmer months, and holomixis and lake level rise during the cooler months of July to September.

The $\mathrm{Mg} / \mathrm{Ca}_{\text {valve }}$ of Gomphodella australica preserved a record of calcite saturation of the upper water column that is comparable to lake level variation; this resulted in rapid water level fluctuations of up to $9 \mathrm{~m}$ during this period. Based on the modern knowledge of the hydrology of Blue Lake, this variation in water level is a reflection of variations of $\mathrm{E} / \mathrm{P}$, with low lake levels occurring in response to arid conditions and high lake levels responding to wetter conditions. The groundwater recharge rate, as reflected in the $\delta^{18} \mathrm{O}_{\text {valve }}$ varied, but did not influence the water level of the lake.

The most recent period, since European settlement of the area (approximately 1840), has resulted in increased volumes of water being removed for human consumption and has significantly increased the recharge rate.

This study also documents the first use of $\mathrm{Na} / \mathrm{Ca}_{\text {valve }}$ determined from ostracods in a lacustrine setting and shows that, at least for Blue Lake, it can be used as a proxy for groundwater contribution as two distinct aquifers have different salinities. For the last $4 \mathrm{ka}$, the $\delta^{18} \mathrm{O}_{\text {valve }}$ is a proxy for groundwater recharge and the $\mathrm{Mg} / \mathrm{Ca}_{\text {valve }}$ records a history of the lake level fluctuations in Blue Lake. This paper presents the first quantified high-resolution lake level curve from southeastern Australia.

Supplementary materials related to this article can be found online at doi:10.1016/j.palaeo.2010.08.005.

\section{Acknowledgments}

This work was funded as part of an ARC Discovery grant (DP0344932) awarded to De Deckker and others, and some of the dates were performed at ANSTO as part of an AINSE grant (AINGRA07037) awarded to PDD. We are grateful to Andy McPharlin for access to Blue Lake and supplying a boat necessary for coring and Colin Magilton of Deakin University facilitated access with a second boat. We would also like to thank Jim Neale for coring the lake, Sharron Glasgow for preliminary pollen work and Judith Shelley and Dr Jessica Reeves for picking samples for geochronology. C.G. thanks Dr Stuart Halse, Jim Cocking, Jane McRae and Adrian Pinder (CALM) for data and discussions of the transfer function, Jeff Lawson (DWLBC) for modern hydrological data and unpublished reports, Linda McMorrow (DEMS) for use of the ICP-AES, Joe Cali (RSES) for use of the Finnigan MAT 251, and Prof. Jonathon Holmes, Dr Paco Mezquita and Prof. Antje Schwalb for comments on an earlier draft. DW thanks Keith Fifield and Steve Tims for running the graphite targets on the 14UV accelerator and Stewart Fallon (RSES) for ${ }^{14} \mathrm{C}$ dating the modern water sample. The manuscript was greatly improved by the helpful and constructive comments of the editor, Prof. Thierry Corrège and two anonymous reviewers.

\section{References}

Anadon, P., Moscariello, A., Rodriguez-Lazaro, J., Filippi, M.L., 2006. Holocene environmental changes of Lake Geneva (Lac Leman) from stable isotopes $\left(\delta^{13} \mathrm{C}\right.$, $\delta^{18} \mathrm{O}$ ) and trace element records of ostracod and gastropod carbonates. Journal of Paleolimnology 35, 593-616.

Ayliffe, L.K., 1983. An isotopic and sedimentological study of the sediments from Blue Lake and Valley Lake, Mount Gambier, South Australia. Unpublished Honours Thesis, Flinders University, p. 104

B.L.M.C., 2001. Our Blue Lake: managing for 2005 and beyond. In: Board, S.E.C.W.M. (Ed.). Blue Lake Management Committee, p. 16.

B.L.M.C., 2006. Blue Lake management plan. In: Board, S.E.N.R.M. (Ed.), Mount Gambier, p. 90 .

Barton, C.E., McElhinny, M.W., 1980. Ages and ashes in lake floor sediment cores from Valley Lake, Mount Gambier, South Australia. Transactions of the Royal Society of South Australia 104, 161-165.

Blackburn, G., 1966. Radiocarbon dates relating to soil development, coast-line changes, and volcanic ash deposition in south-east South Australia. Australian Journal of Science 29, 50-52.

Blackburn, G., Allison, G.B., Leaney, F.W.J., 1982. Further evidence on the age of tuff at Mt Gambier, South Australia. Transactions of the Royal Society of South Australia $106,163-167$.

Blackburn, G., McLeod, S., 1983. Salinity of atmospheric precipitation in the MurrayDarling Drainage Division, Australia. Australian Journal of Soil Research 21, 411-434.

Bowler, J.M., 1981. Australian salt lakes. Hydrobiologia 82, 431-444.

Bowler, J.M., Hamada, T., 1971. Late Quaternary stratigraphy and radiocarbon chronology of water level fluctuations in Lake Keilambete, Victoria. Nature 232, 330-332.

Cali, J.A., 2000. Explanatory notes for data from the Finnigan MAT 251 and Kiel device. http://rses.anu.edu.au/enproc/EP/oz_ms/kiel_expl_notes.html.

Calvo, E., Pelejero, C., De Deckker, P., Logan, G.A., 2007. Antarctic deglacial pattern in a $30 \mathrm{kyr}$ record of sea surface temperature offshore South Australia. Geophysical Research Letters 34, L13707.

Chivas, A.R., De Deckker, P., Cali, J.A., Chapman, A., Kiss, E., Shelley, J.M.G., 1993. Coupled stable-isotope and trace element measurements of lacustrine carbonates as paleoclimatic indicators. In: Swart, P.K. (Ed.), Climate Change in Continental Isotopic Records. American Geophysical Union, pp. 113-121.

Chivas, A.R., De Deckker, P., Shelley, J.M.G., 1983. Magnesium, strontium and barium partitioning in nonmarine ostracode shells and their use in paleoenvironmental 
reconstructions - a preliminary study. In: Maddocks, R.F. (Ed.), Applications of Ostracoda. University Houston Geosciences, Houston, pp. 238-249.

Chivas, A.R., De Deckker, P., Shelley, J.M.G., 1985. Strontium content of ostracods indicates lacustrine palaeosalinity. Nature 316, 250-253.

Chivas, A.R., De Deckker, P., Shelley, J.M.G., 1986. Magnesium content of non-marine ostracod shells: a new palaeosalinometer and palaeothermometer. Palaeogeography, Palaeoclimatology, Palaeoecology 54, 43-61.

Colhoun, E.A., Pola, J.S., Barton, C.E., Heijnis, H., 1999. Late Pleistocene vegetation and climate history of Lake Selina, western Tasmania. Quaternary International 57 (58), $5-23$.

Currey, D.T., 1970. Lake systems, western Victoria. Bulletin of the Australian Limnological Society 3, 1-13.

Curry, B.B., Anderson, T.F., Lohmann, K.C., 1997. Unusual carbon and oxygen isotopic ratios of ostracodal calcite from last interglacial (Sangamon episode) lacustrine sediment in Raymond Basin, Illinois, USA. Journal of Paleolimnology 17, 421-435.

D'Costa, D.M., Edney, P., Kershaw, A.P., De Deckker, P., 1989. Late Quaternary palaeoecology of Tower Hill, Victoria, Australia. Journal of Biogeography 16, 461-482.

De Deckker, P., 1981. Ostracoda from Australian inland waters - notes on taxonomy and ecology. Proceedings of the Royal Society of Victoria 93, 43-85.

De Deckker, P., 1982a. Australian aquatic habitats and biota: their suitability for palaeolimnological investigations. Transactions of the Royal Society of South Australia 106, 145-153.

De Deckker, P., 1982b. Holocene ostracods, other invertebrates and fish remains from cores of four maar lakes in southeastern Australia. Proceedings of the Royal Society of Victoria 94, 183-220.

De Deckker, P., 1983. Notes on the ecology and distribution of non-marine ostracods in Australia. Hydrobiologia 106, 223-234.

De Deckker, P., Bauld, J., Burne, R.V., 1982. Pillie Lake, Eyre Peninsula, South Australia: modern environment and biota, dolomite sedimentation and Holocene history. Transactions of the Royal Society of South Australia 106, 169-181.

De Deckker, P., Chivas, A.R., Shelley, J.M.G., 1999. Uptake of $\mathrm{Mg}$ and $\mathrm{Sr}$ in the euryhaline ostracod Cyprideis determined from in vitro experiments. Palaeogeography, Palaeoclimatology, Palaeoecology 148, 105-116.

De Deckker, P., Forester, R.M., 1988. The use of ostracods to reconstruct continental palaeoenvironmental records. In: De Deckker, P., Colin, J., Peypouquette, J. (Eds.), Ostraocda in the Earth Sciences. Elsevier, Amsterdam, pp. 175-199.

Dodson, J.R., 1974a. Vegetation and climate history near Lake Keilambete, western Victoria. Australian Journal of Botany 22, 709-717.

Dodson, J.R., 1974b. Vegetation history and water fluctuations at Lake Leake, southeastern South Australia. I. 10,000 B.P. to present. Australian Journal of Botany 22, 719-741.

D.W.L.B.C., 2010. http://e-nrims.dwlbc.sa.gov.au/SiteInfo/ 2010

Edney, P., Kershaw, A.P., De Deckker, P., 1990. A Late Pleistocene and Holocene vegetation and environmental record from Lake Wangoom, Western Plains of Victoria, Australia. Palaeogeography, Palaeoclimatology, Palaeoecology 80, 325-343.

Engstrom, D.R., Nelson, S.R., 1991. Paleosalinity from trace metals in fossil ostracodes compared with observational records at Devils Lake, North Dakota, USA. Palaeogeography, Palaeoclimatology, Palaeoecology 83, 295-312.

Fallon, S., 2008. Personal Communication 11/04/2008 to D. Wilkins.

Fifield, L.K., Allan, G.L., Stone, J.O.H., Ophel, T.R., 1994. The ANU AMS system and research program. Nuclear Instruments and Methods in Physics Research Section B: Beam Interactions with Materials and Atoms 92, 85-88.

Fink, D., Hotchkis, M., Hua, Q., Jacobsen, G., Smith, A.M., Zoppi, U., Child, D., Mifsud, C., van der Gaast, H., Williams, A., Williams, M., 2004. The ANTARES AMS facility at ANSTO. Nuclear Instruments and Methods in Physics Research B: Beam Interactions with Materials and Atoms 223-224, 109-115.

Gat, J.R., 1996. Oxygen and hydrogen isotopes in the hydrologic cycle. Annual Review of Earth and Planetary Science 24, 225-262.

Gill, E.D., 1955. Radiocarbon dates for Australian archaeological and geological samples. Australian Journal of Science 18, 49-52.

Gingele, F., De Deckker, P., Hillenbrand, C.D., 2004. Late Quaternary terrigenous sediments from the Murray Canyons area, offshore South Australia and their implications for sea level change, palaeoclimate and palaeodrainage of the MurrayDarling Basin. Marine Geology 212, 183-197.

Gingele, F., De Deckker, P., Norman, M., 2007. Late Pleistocene and Holocene climate of SE Australia reconstructed from dust and river loads deposited offshore the River Murray Mouth. Earth and Planetary Science Letters 255, 257-272.

Gouramanis, C., 2009. High-resolution Holocene palaeoenvironmental and palaeoclimatic changes recorded in southern Australian lakes based on ostracods and their chemical composition. Unpublished PhD Thesis, Research School of Earth Sciences. The Australian National University, Canberra, p. 308.

Gouramanis, C., De Deckker, P., 2010. Alkalinity control on partition coefficients in lacustrine ostracodes from Australia. Geology 38, 359-362.

Herczeg, A.L., Leaney, F.W., Dighton, J.C., Lamontagne, S., Schiff, S.L., Telfer, A.L., English, M.C., 2003. A modern isotope record of changes in water and carbon budgets in a groundwater-fed lake: Blue Lake South Australia. Limnology and Oceanography 48, 2093-2105.

Holmes, J.A., 1996. Trace-element and stable-isotope geochemistry of non-marine ostracod shells in Quaternary palaeoenvironmental reconstruction. Journal of Paleolimnology 15, 223-235.

Holmes, J.A., 2008. Sample-size implications of the trace-element variability of ostracod shells. Geochimica et Cosmochimica Acta 72, 2934-2945.

Holmes, J.A., Chivas, A.R., 2002. Ostracod shell chemistry - overview. In: Holmes, J.A., Chivas, A.R. (Eds.), The Ostracoda: Applications in Quaternary Research: American Geophysical Union, Washington D.C. , pp. 185-204.
Holmes, J.A., Street-Perrott, F.A., Allen, M.J., Fothergill, P.A., Harkness, D.D., Kroon, D. Perrott, R.A., 1997. Holocene palaeolimnology of Kajemarum Oasis, Northern Nigeria: an isotopic study of ostracodes, bulk carbonate and organic carbon. Journal of the Geological Society, London 154, 311-319.

Holmes, J.W., Waterhouse, J.D., 1983. 6: Hydrology. In: Tyler, M.J., Twidale, C.R., Ling, J.K. Holmes, J.W. (Eds.), Natural history of the South East. Royal Society of South Australia Inc., pp. 49-59.

http://www.bom.gov.au/climate/averages/tables, 2008. Mount Gambier.

http://www.mountgambiertourism.com.au/, 2007. Mount Gambier Tourism.

Ito, E., 2002. $\mathrm{Mg} / \mathrm{Ca}, \mathrm{Sr} / \mathrm{Ca}, \delta^{18} \mathrm{O}$ and $\delta^{13} \mathrm{C}$ chemistry of Quaternary lacustrine ostracode shells from the North American continental interior. In: Holmes, J.A., Chivas, A.R (Eds.), The Ostracoda: Applications in Quaternary Research. Washington D.C., American Geophysical Union.

Ito, E., De Deckker, P., Eggins, S.M., 2003. Ostracodes and their shell chemistry: implications for paleohydrologic and paleoclimatologic applications. The Palaeontological Society Papers 9, 119-152.

Ito, E., Forester, R.M., 2009. Changes in continental ostracode shell chemistry; uncertainty of cause. Hydrobiologia 620, 1-15.

Jones, R.N., Bowler, J.M., McMahon, T.A., 1998. A high resolution Holocene record of P/E ratio from closed lakes, western Victoria. Palaeoclimates 3, 51-82.

Jones, R.N., McMahon, T.A., Bowler, J.M., 2001. Modelling historical lake levels and recent climate at three closed lakes, Western Victoria, Australia (c. 1840-1990). Journal of Hydrology 246, 159-180.

Juggins, S., 2003. C2 User guide. Software for ecological and palaeoecological data analysis and visualisation. University of Newcastle, Newcastle upon Tyne, 69 pp.

Keatings, K.W., Heaton, T.H.E., Holmes, J.A., 2002. Carbon and oxygen isotope fractionation in non-marine ostracods: results from 'natural culture' environment. Geochimica et Cosmochimica Acta 66, 1701-1711.

Kigoshi, K., Kobayashi, H., 1966. Gakushuin natural radiocarbon measurements V. Radiocarbon 8, 54-73.

Lambeck, K., Chappell, J.C., 2001. Sea level changes through the last glacial cycle. Science 292, 679-686.

Leaney, F.W.J., Allison, G.B., Dighton, J.C., Trumbore, S., 1995. The age and hydrological history of Blue Lake, South Australia. Palaeogeography, Palaeoclimatology, Palaeoecology 118, 111-130.

Li, H.-C., Ku, T.-L., 1997. $\delta^{13} \mathrm{C}-\delta^{18} \mathrm{O}$ covariance as a paleohydrological indicator for closed-basin lakes. Palaeogeography, Palaeoclimatology, Palaeoecology 133 , 69-80.

Li, Q., McGowran, B., White, M.R., 2000. Sequences and biofacies packages in the midCenozoic Gambier Limestone, South Australia: reappraisal of foraminiferal evidence. Australian Journal of Earth Sciences 47, 955-970.

Love, A.J., Herczeg, A.L., Armstrong, D., Stadter, F., Mazor, E., 1993. Groundwater flow regime within the Gambier Embayment of the Otway Basin, Australia: evidence from hydraulics and hydrochemistry. Journal of Hydrology 143, 297-338.

Love, A.J., Herczeg, A.L., Leaney, F.W., Stadter, F., Dighton, J.C., Armstrong, D., 1994 Groundwater residence time and palaeohydrology in the Otway Basin, South Australia: ${ }^{2} \mathrm{H},{ }^{18} \mathrm{O}$ and ${ }^{14} \mathrm{C}$ data. Journal of Hydrology $153,157-187$.

Mayewski, P., Rohling, E.E., Stager, J.C., Karlén, W., Maasch, K.A., Meeker, L.D., Meyerson, E.A., Gasse, F., van Kreveld, S., Holmgren, K., Lee-Thorp, J., Rosqvist, G., Rack, F., Staubwasser, M., Schneider, R.R., Steig, E.J., 2004. Holocene climate variability. Quaternary Research 62, 243-255.

McCormac, F.G., Hogg, A.G., Blackwell, P.G., Buck, C.E., Higham, T.F.G., Reimer, P.J., 2004 SHCal04 Southern Hemisphere Calibration 0-11.0 cal kyr BP. Radiocarbon 46, 1087-1092.

McKenzie, G.M., Kershaw, A.P., 1997. A vegetation history and quantitative estimate of Holocene climate from Chapple Vale, in the Otway Region of Victoria, Australia. Australian Journal of Botany 45, 565-581.

Mischke, S., Wunnemann, B., 2006. The Holocene salinity history of Bosten Lake (Xinjiang, China) inferred from ostracod species assemblages and shell chemistry: possible palaeoclimatic implications. Quaternary International 154-155, 100-112.

Moros, M., De Deckker, P., Jansen, E., Perner, K., Telford, R.J., 2009. Holocene climate variability in the Southern Ocean recorded in a deep-sea sediment core off South Australia. Quaternary Science Reviews 28, 1932-1940.

Ramamurthy, L.M., Veeh, H.H., Holmes, J.W., 1985. Geochemical mass balance of a volcanic crater lake in Australia. Journal of Hydrology 79, 127-139.

Ricketts, R.D., Johnson, T.C., Brown, E.T., Rasmussen, K.A., Romanovsky, V.V., 2001. The Holocene paleolimnology of Lake Issyk-Kul, Kyrgyzstan: trace element and stable isotope composition of ostracodes. Palaeogeography, Palaeoclimatology, Palaeoecology 176, 207-227.

Schwalb, A., 2003. Lacustrine ostracodes as stable isotope recorders of late-glacial and Holocene environmental dynamics and climate. Journal of Paleolimnology 29 267-351.

Sheard, M.J., 1978. Geological history of the Mount Gambier volcanic complex, southeast South Australia. Transactions of the Royal Society of South Australia $102,125-139$.

Stanley, S., De Deckker, P., 2002. A Holocene record of allochthonous, aeolian minera grains in an Australian alpine lake; implications for the history of climate change in southeastern Australia. Journal of Paleolimnology 27, 207-219.

Stuiver, M., Polach, H.A., 1977. Discussion and reporting of ${ }^{14} \mathrm{C}$ data. Radiocarbon 19, 355-363.

Stuiver, M., Reimer, P.J., 1993. Extended ${ }^{14} \mathrm{C}$ database and revised CALIB $3.0{ }^{14} \mathrm{C}$ age calibration program. Radiocarbon 35, 215-230.

Talbot, M.R., 1990. A review of the palaeohydrological interpretation of carbon and oxygen ratios in primary lacustrine carbonates. Chemical Geology 80, 261-279l.

Tamuly, A., 1970. Physical and chemical limnology of the Blue Lake of Mount Gambier South Australia. Transactions of the Royal Society of South Australia 94, 71-86. 
Telfer, A.L., 2000. Identification of processes regulating the colour and colour change in an oligotrophic, hardwater, groundwater-fed lake, Blue Lake, Mount Gambier, South Australia. Lakes and Reservoirs: Research and Management 5, 161-176.

Turner, J.V., Allison, G.B., Holmes, J.W., 1984. The water balance of a small lake using stable isotopes and tritium. Journal of Hydrology 70, 199-220.

Turpen, J.B., Angell, R.W., 1971. Aspects of moulting and calcification in the ostracod Heterocypris. Biological Bulletin 140, 331-338.

Vanderzalm, J., Dillon, P.P., D., Marvanek, S., Lamontagne, S., Cook, P., King, H., Dighton, J.C Sherman, B., Adams, L., 2009. Protecting Blue Lake from land use impacts. In: CSIRO (Ed.). Water for a Healthy Country National Research Flagship, 94 pp.

von Grafenstein, U., Erlenkeuser, H., Brauer, A., Jouzel, J., Johnsen, S., 1999a. A mid European decadal isotope-climate record from 15,500 to 5000 years BP. Science 284 , $1654-1657$.

von Grafenstein, U., Erlenkeuser, H., Trimborn, P., 1999b. Oxygen and carbon isotopes in modern fresh-water ostracod valves: assessing vital offsets and autecologica effects of interest for paleoclimate studies. Palaeogeography, Palaeoclimatology, Palaeoecology 148, 133-152.

Waterhouse, J.D., 1977. The hydrogeology of the Mount Gambier area. Geological Survey of South Australia, Report of Investigations No 48, 61 pp.

Wilkins, D., 2009. Comparative Optical Stimulated Luminescence and Radiocarbon dating of Holocene lacustrine and marine deposits in south-east and south-west Australia., Unpublished PhD Thesis, Research School of Earth Sciences. The Australian National University, Canberra, p. 460.

Wilkins, D., Gouramanis, C., De Deckker, P., Fifield, K.L., Olley, J., in preparation. New Holocene lake level curves from Lake Keilambete and Lake Gnotuk, south-western Victoria, Australia: comparative OSL and radiocarbon dating of two sedimentary sequences.

Xia, Q., Zhao, J., Collerson, K.D., 2001. Early-Mid Holocene climatic variations in Tasmania, Australia: multi-proxy records in a stalagmite from Lynds Cave. Earth and Planetary Science Letters 194, 177-187. 